\title{
Can greenhouse gases in breath be used to genetically improve feed efficiency of dairy cows?
}

\author{
G. F. Difford, ${ }^{1,2 *} \odot$ P. Løvendahl, ${ }^{1} \oplus$ R. F. Veerkamp, ${ }^{2} \odot$ H. Bovenhuis, ${ }^{2} \oplus$ M. H. P. W. Visker, ${ }^{2} \oplus$ J. Lassen, $^{3}$ \\ and Y. de Haas $^{2}$ (1) \\ ${ }^{1}$ Center for Quantitative Genetics and Genomics, Department of Molecular Biology and Genetics, Aarhus University, Blichers Alle 20, 8830, \\ Tjele, Denmark \\ ${ }^{2}$ Wageningen University \& Research Animal Breeding and Genomics, $6700 \mathrm{AH}$ Wageningen, the Netherlands \\ ${ }^{3}$ Viking Genetics, Ebeltoftvej 16, Assentoft, 8960 Randers, Denmark
}

\section{ABSTRACT}

There is considerable interest in improving feed utilization of dairy cattle while limiting losses to the environment (i.e., greenhouse gases, GHG). To breed for feed-efficient or climate-friendly cattle, it is first necessary to obtain accurate estimates of genetic parameters and correlations of feed intake, greenhouse gases, and production traits. Reducing dry matter take (DMI) requirements while maintaining production has high economic value to farmers, but DMI is costly to record and thus limited to small research or nucleus herds. Conversely, enteric methane $\left(\mathrm{CH}_{4}\right)$ currently has no economic value, is also costly to record, and is limited to small experimental trials. However, breath gas concentrations of methane $\left(\mathrm{CH}_{4} \mathrm{c}\right)$ and carbon dioxide $\left(\mathrm{CO}_{2} \mathrm{c}\right)$ are relatively cheap to measure at high throughput under commercial conditions by installing sniffers in automated milking stations. The objective of this study was to assess the genetic correlations between DMI, body weight (BW), fat- and protein-corrected milk yield (FPCM), and GHG-related traits: $\mathrm{CH}_{4} \mathrm{C}$ and $\mathrm{CO}_{2} \mathrm{C}$ from Denmark (DNK) and the Netherlands (NLD). A second objective was to assess the genetic potential for improving feed efficiency and the added benefits of using $\mathrm{CH}_{4} \mathrm{C}$ and $\mathrm{CO}_{2} \mathrm{C}$ as indicators. Feed intake data were available on 703 primiparous cows in DNK and 524 in NLD; $\mathrm{CH}_{4} \mathrm{c}$ and $\mathrm{CO}_{2} \mathrm{c}$ records were available on 434 primiparous cows in DNK and 656 in NLD. The GHG-related traits were heritable (e.g., $\left.\mathrm{CH}_{4} \mathrm{c} h^{2}: \mathrm{DNK}=0.26, \mathrm{NLD}=0.15\right)$ but were differentially genetically correlated with DMI and feed efficiency in both magnitude and sign, depending on the population and the definition of feed efficiency. Across feed efficiency traits and DMI, having bulls with 100

Received May 15, 2019.

Accepted November 21, 2019.

*Corresponding author: gareth.difford@mbg.au.dk daughters with FPCM, BW, and GHG traits resulted in sufficiently high accuracy to almost negate the need for DMI records. Despite differences in genetic correlation structure, the relatively cheap GHG-related traits showed considerable potential for improving the accuracy of breeding values of highly valuable feed intake and feed efficiency traits.

Key words: methane, carbon dioxide, breath gas measurement, residual feed intake, feed efficiency

\section{INTRODUCTION}

The dairy industry faces major challenges to remain profitable while maintaining environmental sustainability (i.e., by mitigating greenhouse gas emissions such as $\mathrm{CH}_{4}$ and $\mathrm{CO}_{2}$ ). Feed plays a crucial role in economic and environmental performance of dairy production units because feed constitutes the highest variable cost of production (Hemme et al., 2014), and feed composition affects $\mathrm{CH}_{4}$ emissions at an individual cow level (Hristov et al., 2013). The primary income from milk is volatile as milk prices often fail to increase with feed prices (Hemme et al., 2014). One promising way to increase profitability is to reduce feed costs by reducing feed intake requirements and improving or maintaining production in the breeding objective (Veerkamp, 1998; de Haas et al., 2012); that is, identifying cows that require less feed to give the same levels of production as contemporaries, without hampering traits in the selection index such as health and fertility.

However, feed efficiency is not directly observable; rather it is feed intake conditional on a combination of production traits or energy sinks; for example, fatand protein-corrected milk (FPCM), BW, and so on (Jensen et al., 1992). The most prevalent feed intake trait across countries is DMI because this accounts for differences in moisture content of feeds (Berry et al., 2014). The recording of DMI is labor intensive, expensive, and limited to small research or nucleus herds; 
therefore, the reliability of bull breeding values is low (de Haas et al., 2012). This could, in principle, be overcome by including heritable and correlated indicator traits measured on a large scale in commercial herds in conjunction with smaller research herds with DMI recording (Berry and Crowley, 2013; Manzanilla-Pech et al., 2016; Wallén et al., 2017).

Defining feed efficiency is challenging because DMI is highly genetically correlated with production traits such as FPCM and BW, and these genetic relationships can vary across research stations, diets, and parities (Tempelman et al., 2015; Li et al., 2017). Feed efficiency traits such as feed conversion ratio and phenotypic residual feed intake (RFIp) retain genetic correlations with production traits (de Haas et al., 2011; Manafiazar et al., 2016). Kennedy et al. (1993) used restricted selection indices to define genetic residual feed intake (RFIg) as DMI genetically independent of FPCM and $\mathrm{BW}$, overcoming the deficiencies of ratio or phenotypic regression residual definitions of feed efficiency ( $\mathrm{Lu}$ et al., 2015). However, large numbers of records on cows are needed to estimate genetic correlations among DMI, FPCM, and BW accurately to compute RFIg. Increasing the numbers of records has been achieved by combining research herds (Berry et al., 2014). However, combining different herds or multiple records within and over lactation results in heterogeneity due to diet and lactation stage in the relationships between DMI and energy sink traits (Tempelman et al., 2015; Li et al., 2017; Lu et al., 2017). Given the difficulties in obtaining DMI records on large numbers of cows within country, the need exists for other easily recorded, largescale indicator traits genetically correlated with DMI and feed efficiency.

Studies using intensive "gold standard" respiration chambers (RC) have shown high phenotypic correlations between mass fluxes of the greenhouse gas traits (GHG) $\mathrm{CH}_{4}$ and $\mathrm{CO}_{2}$ (Aubry and Yan, 2015; Difford et al., 2018). Furthermore, the caloric value of $\mathrm{CH}_{4}$ has been estimated as 2 to $12 \%$ of the gross energy intake of the cow (Johnson and Johnson, 1995). This has led to numerous prediction equations using DMI and feed components to predict $\mathrm{CH}_{4}$ production (Ramin and Huhtanen, 2013) and genetic parameters for predicted $\mathrm{CH}_{4}$ emission from metabolizable energy intake (de Haas et al., 2011; Negussie et al., 2014). Furthermore, predicted $\mathrm{CH}_{4}$ emission was favorably genetically correlated with phenotypic RFI (de Haas et al., 2011). Thus, turning this idea around, GHG traits could be indicators of DMI and feed efficiency traits. However, $\mathrm{RC}$ have high capital and labor costs and have mostly proven prohibitive to large-scale genetic evaluations, with the largest studies using RC reaching approxi- mately 1,000 individuals in growing beef or mixed sheep breeds (Pinares-Patiño et al., 2013; Donoghue et al., 2016; Jonker et al., 2018). Furthermore, confinement within the RC affects natural animal behavior and can cause a decrease in DMI, leading many to question the extrapolation of these results to intensive commercial and grazing systems (Pinares-Patiño and Clark, 2008). Thus, the potential of GHG traits recorded using RC as indicator traits remains limited.

A cost-effective and high-throughput method of recording methane $\left(\mathbf{C H}_{4} \mathbf{c}\right)$ and carbon dioxide concentrations $\left(\mathbf{C O}_{2} \mathbf{c}\right)$ in the breath of individual cows while milking in commercial automated milking stations (AMS) has emerged (Garnsworthy et al., 2012a; Lassen et al., 2012) with the use of devices collectively known as sniffers. Because sniffers record gas concentrations and not mass fluxes, researchers have used scaling factors (Garnsworthy et al., 2012b) or predicted $\mathrm{CO}_{2}$ as a tracer gas to approximate $\mathrm{CH}_{4}$ mass fluxes (Madsen et al., 2010). These approximations have been shown to be heritable and genetically correlated with FPCM and $\mathrm{BW}$, and they have good concordance (concordance correlation coefficient $=0.65-0.93$ ) with $\mathrm{RC}$ (Garnsworthy et al., 2012b; Lassen and Løvendahl, 2016; Negussie et al., 2016). The direct measures $\mathrm{CH}_{4} \mathrm{c}$ and $\mathrm{CO}_{2} \mathrm{c}$ have been reported as lowly heritable in dairy cattle: $h^{2}=$ 0.11 and 0.12, respectively (van Engelen et al., 2018). However, the genetic correlations of $\mathrm{CH}_{4} \mathrm{c}$ and $\mathrm{CO}_{2} \mathrm{C}$ with feed intake and production traits are currently not known, and their potential as indicator traits for DMI and feed efficiency traits is under-exploited.

The first aim of this study was to estimate genetic parameters for feed intake-related traits and GHG-related traits in primiparous Holsteins in Denmark (DNK) and the Netherlands (NLD). The second aim was to assess the use of breath concentration GHG traits as large-scale indicators for improving the accuracy of DMI and feed efficiency breeding values.

\section{MATERIALS AND METHODS}

\section{Design and Animals}

Data on individual DMI, BW, FPCM, $\mathrm{CH}_{4} \mathrm{c}$, and $\mathrm{CO}_{2} \mathrm{C}$ were collected repeatedly over lactation in primiparous Danish Holstein and Dutch Holstein Friesian cows. Primiparous cows were the focus of this study to avoid heterogeneity in genetic and phenotypic parameters due to parity classes. Primiparous cows were the largest parity class in both countries. Both countries have recorded DMI, BW, and FPCM in indoor research herds over the last few decades, with numerous nutritional trials of various TMR feeds, and expressed 
these as weekly averages for genetic evaluations. More recently, both countries have installed sniffers in AMS at research stations and in commercial herds for the repeated recording of $\mathrm{CH}_{4} \mathrm{c}$ and $\mathrm{CO}_{2} \mathrm{c}$, expressed as weekly averages. Commercial herds were included to improve the representativeness of the genetic parameters estimated and convergence of multi-trait animal models, because these herds had $\mathrm{CH}_{4} \mathrm{c}, \mathrm{CO}_{2} \mathrm{c}, \mathrm{FPCM}$, and BW. The data collection, editing, and analysis are presented below.

\section{Data Collection and Editing: Feed Intake Traits}

Denmark. A total of 25,109 weekly averaged records for DMI, BW, and milk yield (MY) were available on 703 primiparous Danish Holstein cows that calved from 2000 to 2015 at the Danish Cattle Research Center (DCRC, Foulum, Denmark; Li et al., 2017). The DCRC barn is a loose-housing system in which cows have ad libitum access to feed in individual automated feed bins (RIC system, Insentec B.V., Marknesse, the Netherlands). Cows also had access to an AMS (DeLaval AB, Tumba, Sweden) where they were offered up to $3 \mathrm{~kg}$ of concentrate per day within the integral AMS feed bins. The AMS was fitted with a weighing platform (Danvaegt, Hinnerup, Denmark) to record BW at each milking and a device that delivered and recorded the amounts of concentrates and refusals.

Cows were entered in numerous nutritional trials at DCRC and have remained on a largely unchanged control TMR diet in between trials, which consists of rolled barley, corn silage, grass clover silage, rapeseed meal, and soybean meal. The DM contents of the TMR and concentrates in the AMS were determined from regular analysis and combined with averaged weekly feed intake to obtain DMI per cow per week of lactation. Although many trials calculated energy contents of specific feed treatments, energy intake was largely unavailable for most cows. The diets within a specific treatment are expected to be the same, whereas dietary differences between treatments are expected to change. Furthermore, the dietary composition of the control diets can be expected to change with the effects of year and season on feed ingredients (Nielsen et al., 2003). Thus, an experiment $\times$ treatment interaction term was created, which corresponds to the experimental trial and specific treatment in the case of nutritional experiments and a year $\times$ season variable for the control diet. This method of modeling the changes in ration is consistent with modeling longitudinal intake data in other international genetic evaluations such as the global dry matter initiative (gDMI; Berry et al., 2014).

Milk composition was determined from every milking over a consecutive 48-h period in each week using a
CombiFoss (Foss, Hillerød, Denmark) operated by Eurofins (Vejen, Denmark). Composition data from each milking were used to calculate yields of fat and protein, which were smoothed by the moving average method to obtain daily yields. The calculated yields were averaged per week so that weekly records were on the same time scale as DMI records. The DCRC records for BW, MY, and DMI were filtered to remove weekly averages where more than 2 days of records were missing. Cows that had $<5$ weekly records during their first lactation or an age of first calving $>36$ mo were excluded. Although many of the experimental treatments were carefully blocked and balanced, these trials often included multiparous cows, which were not the focus of the present study. Thus, a filter of a minimum of 5 cows per experimental treatment was added to ensure adequate degrees of freedom for effect estimation. The records after editing are summarized in Table 1, with data set DNK1 corresponding to DCRC.

The Netherlands. In total, 14,015 weekly averaged records for DMI, BW, and MY were included in the analysis on 721 primiparous Dutch Holstein cows that calved from 2000 to 2015. The Dutch data comprised multiple nutritional experiments conducted at several locations in the Netherlands (e.g., Aver Heino; Bosma Zathe, Ureterp; Cranendonck, Soerendonk; 't Gen, Lelystad; Minderhoudhoeve, Swifterbant; Waiboerhoeve Dairy unit 2, 3, Lelystad; Zegveld farm, Zegveld; Hoorn, Lelystad; New Waiboerhoeve, Lelystad; Dairy Campus, Lelystad). Data from these farms were classified into 2 data sets based on previous studies (NLD1 and NLD2), for which data collection has been described (see Table 1; Veerkamp et al., 2000; Beerda et al., 2007; Zom et al., 2012; van Knegsel et al., 2014). All herds were indoor housing and offered TMR that primarily consisted of grass silage, fresh grass, dehydrated grass, corn, corn silage, cereal, concentrates, or beet pulp. Milking was conducted twice daily for most herds, except for the AMS herds where milking frequency is based on voluntary milking. Feed intake was recorded using individual automated feed bins (RIC system, Insentec B.V.). In general, BW was recorded either 3 times a week using automatic weighing platforms or in the AMS integral automatic weighing platforms. As with the Danish data set, cows in the Dutch data sets were entered in numerous nutritional trials, and the assumptions about diets within and between trials are the same. The DM composition of diets was used to calculate DMI, but the specific dietary composition and energy of many diets were not available. Fat and protein contents of milk were recorded at least once per week in all data sets. Data editing steps included only retaining cows with a Holstein breed percentage of $75 \%$ or greater, a minimum of 5 observations per experimen- 
tal treatment and 5 records per cow, and calving no later than 36 mo of age.

Fat- and protein-corrected milk yield was calculated for both Denmark and the Netherlands using a single standardization equation of $4.0 \%$ fat and $3.3 \%$ protein as recommended in FAO (2010): FPCM $(\mathrm{kg})=(0.337$ $\times$ milk yield $\mathrm{kg})+(11.6 \times$ fat yield $\mathrm{kg})+(5.999 \times$ protein yield) (CVB, 2008).

\section{Data Collection and Editing: GHG Traits}

Denmark. Data on the $\mathrm{CH}_{4} \mathrm{C}$ and $\mathrm{CO}_{2} \mathrm{C}$ of individual Holstein cows during milking was available on 232 primiparous cows at DCRC from mid 2013 to November 2016, with simultaneous DMI, FPCM, and $\mathrm{BW}$ records. The nondispersive infrared (NDIR) $\mathrm{CH}_{4}$ sensor (Guardian NG, Edinburgh Instruments Ltd., Livingston, UK) and the NDIR $\mathrm{CO}_{2}$ sensor (Gascard, Edinburgh Instruments Ltd.) were installed in each of the AMS. The equipment installation, technical specifications, and calibration procedures for the sensors are described elsewhere (Difford et al., 2016). The timestamped AMS visit data and breath gas concentration time series on a 1-s basis were merged using a timealignment algorithm (Difford et al., 2016). Gas data from AMS milkings $<300 \mathrm{~s}$ and marked as incomplete or interrupted by the AMS were removed. A cow headlifting algorithm was used to filter out gas readings when the cow's head is predicted to be outside of the feed bin (Difford et al., 2016). The ambient background gas concentrations of $\mathrm{CH}_{4} \mathrm{c}$ and $\mathrm{CO}_{2} \mathrm{C}$ were estimated once daily during the morning cleaning cycle of the AMS, when the AMS is free of cows, and subtracted from the mean $\mathrm{CH}_{4} \mathrm{C}$ and $\mathrm{CO}_{2} \mathrm{C}$ of each milking for that day.

Greenhouse gas measurements were also taken in 2 commercial herds in Denmark from November 2015 until March 2016 as part of the REMRUM project. A portable set of 4 NDIR sensors as above and 1 portable Fourier transform infrared (FTIR) Gasmet DX-4000 sensor (Gasmet; Gasmet Technologies Oy, Helsinki, Finland), which registers gas concentrations on a 5 -s basis, were used. The use of FTIR equipment in commercial herds is described elsewhere (Lassen and Løvendahl, 2016). The data from commercial herds were handled the same as that from the research herd described above. Sensors were installed in AMS (Astronaut A3, Lely Industries, NV, Maassluis, the Netherlands) equipped with weighing platforms. The milk components were taken from the national recording scheme (RYK, Skejby, Denmark), and cow FPCM yield (CVB, 2008; FAO, 2010) was estimated as in the Dutch population.

Data from the research and commercial herds were filtered to include only weekly averages with a maximum of $3 \mathrm{~d}$ missing per week of measurement and a minimum of 3 weekly measurements per cow (Table 1). The effect of contemporary group and AMS were,

Table 1. Description of available phenotypic records for first-parity Holstein Friesian cows in Denmark and the Netherlands

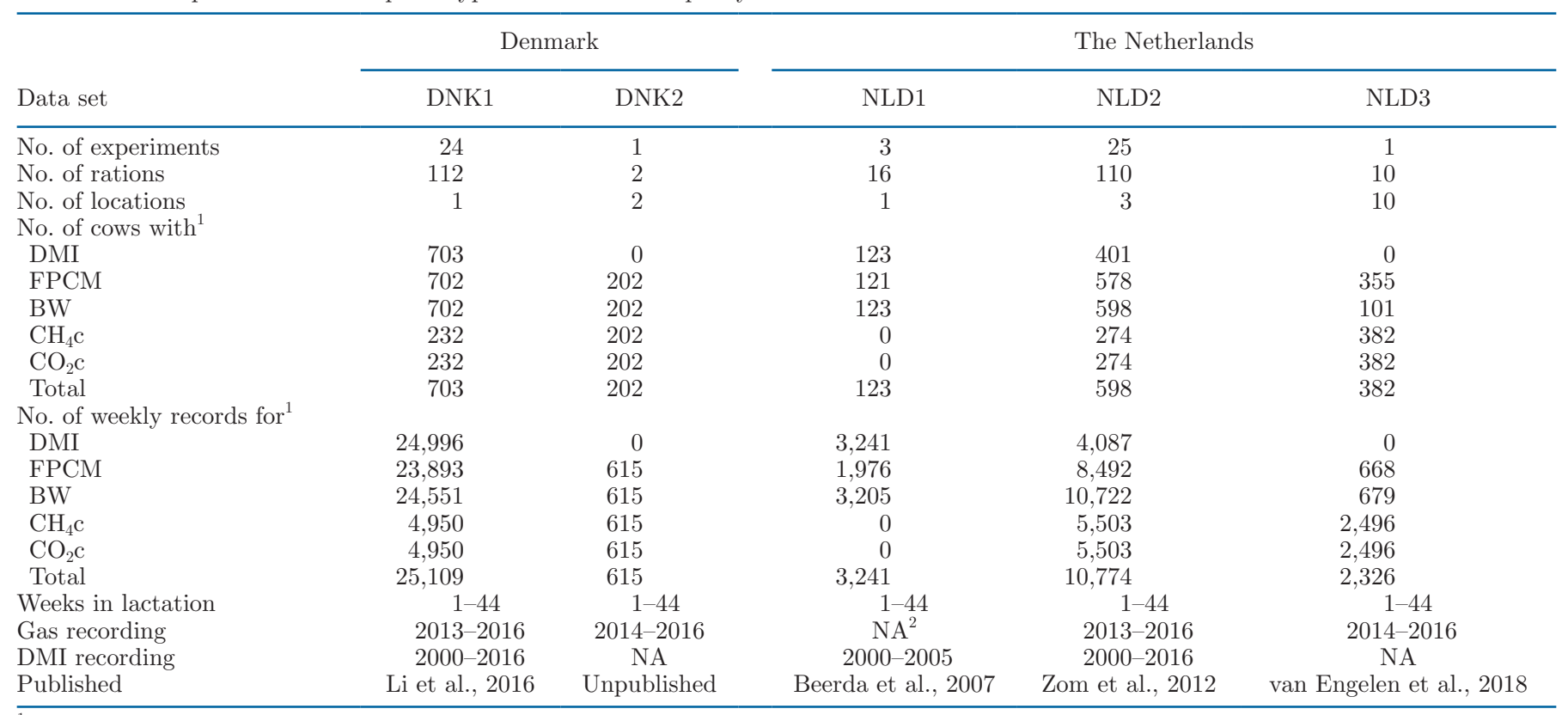

${ }^{1} \mathrm{FPCM}=$ fat- and protein-corrected milk yield; $\mathrm{CH}_{4} \mathrm{c}=$ methane breath concentration; $\mathrm{CO}_{2} \mathrm{c}=$ carbon dioxide breath concentration .

${ }^{2} \mathrm{NA}=$ not applicable. 
by necessity, confounded at DCRC and were thus also confounded with the experiment $\times$ treatment interaction described for the feed intake traits. The commercial herds maintained the same diet while gases were recorded; a variable of year $\times$ season $\times$ AMS group nested within herd was used in place of the experiment $\times$ treatment term used in the research herds. Similarly, gas traits were filtered to ensure each experiment $x$ treatment interaction term had at least 5 cows and a minimum of 5 weekly records per cow. The data set from DCRC corresponded to DNK1 and that for commercial herds corresponded to DNK2 (Table 1).

The Netherlands. Data on the $\mathrm{CH}_{4} \mathrm{c}$ and $\mathrm{CO}_{2} \mathrm{c}$ of individual Holstein cows during milking was available on 274 primiparous cows at Dairy Campus Lelystad (NLD2) from October 2013 to November 2016, with simultaneous FPCM and BW records. The NLD2 cows were grouped into 2 AMS groups without access to automatic feed bins. Thus, cows were tested for 1 to $70 \mathrm{~d}$ for DMI and then moved to the AMS groups, where gas recording took place; therefore, no simultaneous week of lactation records for DMI and gases were available in the Netherlands. The FTIR sensor inlet was installed in the integral feed bins of 2 AMS (Astronaut A3, Lely Industries NV), where gases were drawn from each of the AMS on alternating days. The time-stamped AMS visit data and breath gas concentration time series on a 5 -s basis were merged. The air sampled for the first $20 \mathrm{~s}$ of each visit was discarded to ensure no carryover of gas readings from the previous cow's milking. Data from milkings that lasted less than $120 \mathrm{~s}$ and data collected after $600 \mathrm{~s}$ of the start of the milking were excluded. Milkings marked as errors by the AMS were also excluded. The ambient background concentrations were estimated in the same manner as those from the Danish sniffer data. After editing, 5,503 weekly average records were available on 274 primiparous Holstein cows, corresponding to data set NLD2 (Table 1 ).

Data for $\mathrm{CH}_{4} \mathrm{C}$ and $\mathrm{CO}_{2} \mathrm{C}$ on 382 primiparous Dutch Holstein Friesian cows from 11 commercial herds were collected from November 2013 to March 2016 as part of the TiFN project "Reduced methane emission of dairy cows" (NLD3; Table 1). Four portable NDIR sensors (SenseAir LPL $113 \mathrm{CH}_{4} / \mathrm{CO}_{2}$, Rise Acreo, Stockholm, Sweden) were installed in the integral feed bin of the AMS (Lely, Astronaut A4, Lely Industries NV) with twice per second recordings. The sampling strategies, installation, and phenotype calculation has been described elsewhere (van Engelen et al., 2018). Briefly, the time series data were aligned to the AMS data by a function that maximizes $\mathrm{CH}_{4} \mathrm{c}$ and $\mathrm{CO}_{2} \mathrm{C}$ during visits and minimizes $\mathrm{CH}_{4} \mathrm{c}$ and $\mathrm{CO}_{2} \mathrm{c}$ between visits. Visits shorter than $90 \mathrm{~s}$ were removed. The background concentration for $\mathrm{CH}_{4} \mathrm{c}$ was assumed to be $0 \mathrm{ppm}$ and that for $\mathrm{CO}_{2} \mathrm{C} 400 \mathrm{ppm}$; these values were subtracted from the mean of 10 minimum recordings per visit and subtracted from the mean of the visit to approximate background-corrected $\mathrm{CH}_{4} \mathrm{c}$ and $\mathrm{CO}_{2} \mathrm{C}$ means per milking (van Engelen et al., 2018). The $\mathrm{CH}_{4} \mathrm{C}$ and $\mathrm{CO}_{2} \mathrm{C}$ per milking were combined with the MY per milking. Where possible, mean BW per milking was retained; however, the majority of AMS were not equipped with integral weighing platforms so BW was not available from all locations. Records on milk components during the sampling periods for each herd were acquired from the cooperative cattle improvement organization CRV (Arnhem, the Netherlands) to estimate FPCM.

Data from the research and commercial herds were filtered using the same steps for weekly measures per cow and the same experiment $x$ treatment interaction term for feed intake traits and year $\times$ season $\times$ AMS group nested within herd term for GHG traits (Table $1)$.

\section{Data Collection and Editing: Pedigrees}

Pedigree information of all animals was traced back to founder generations, by extracting the Danish and Dutch pedigrees from the Nordic Cattle Genetic Evaluation Database (NAV, Skejby, Denmark) and the cooperative cattle improvement organization (CRV). Noninformative individuals in the pedigrees were removed with the DMU Trace program (Madsen, 2012). The total DNK pedigree consisted of 9,774 animals and the NLD pedigree included 8,042 animals.

\section{Statistical Analysis}

Cows had multiple records for $\mathrm{CH}_{4} \mathrm{c}$ and $\mathrm{CO}_{2} \mathrm{C}$ per day made at different times per day. The starting time for each visit in the AMS was converted to 24-h angular radians for further modeling of diurnal variation in a Fourier series approach (Lassen et al., 2012; Lassen and Løvendahl, 2016). A precorrection model within AMS group for all herds in all countries was used to estimate the daily breath gas concentration free of the effects of diurnal variation, sensor drift after calibration, and test-day variation between calibrations:

$y_{i j k l m}=\mu+d_{i}+b_{j}+\sum_{k=1}^{3}\left(f_{1 k} \sin \theta+f_{2 k} \cos \theta\right)+c_{l}+e_{i j k l m}$,

where $y_{i j k l m}$ is the natural logarithm of backgroundcorrected AMS visit means of $\mathrm{CH}_{4} \mathrm{c}$ and $\mathrm{CO}_{2} \mathrm{c} ; d_{i}$ is the 
fixed effect of test-day $i ; b_{j}$ is the fixed effect of the first full day after each calibration $j ; f_{1 k}$ and $f_{2 k}$ are harmonic pairs of the fixed regression coefficients of Fourier series linear covariates of the time of day of measurement. Here, $\theta$ denotes the time of visit expressed as $24-\mathrm{h}$ angular radians. Term $c_{l}$ is the random effect parameters for each cow $c_{l} \sim N D\left(0, \sigma_{c}^{2}\right)$, where $\sigma_{c}^{2}$ is the cow variance and $e_{i j k l m}$ is the random residual $\sim N D\left(0, \mathbf{I} \sigma_{e}^{2}\right)$, where $\sigma_{e}^{2}$ is the residual variance. To correct daily AMS visit means, the random residuals for each visit were summed with random cow solutions, intercept, calibration day, and the regression coefficients $f_{1 k}$ and $f_{2 k}$ multiplied by the angular radian corresponding to 12:00:00 $(1200 \mathrm{~h})$. Further, $\mathrm{CH}_{4} \mathrm{c}$ and $\mathrm{CO}_{2} \mathrm{c}$ in natural log-transformed parts per million, as the average per week of lactation, were obtained by taking the corrected means of visits weighted by the number of seconds for each visit where the cow head was positioned correctly in the feed bin.

Univariate repeatability mixed models were conducted in Proc Mixed in SAS (version 9.3, SAS Institute Inc., Cary, NC), where significance of fixed effects was tested using the Kenward-Roger correction for the correct denominator degrees of freedom, for all traits within country. The residuals were tested for deviations from normality by means of Kolmogorov-Smirnov normality tests and visual appraisal of residual diagnostic plots. Severe violations were detected for $\mathrm{CH}_{4} \mathrm{C}$ and $\mathrm{CO}_{2} \mathrm{c}$, which were best remedied by a natural logtransformation and henceforth referred to as $\operatorname{lnCH}_{4} \mathrm{C}$ and $\operatorname{lnCO}_{2} \mathrm{c}$. The means and variances of $\operatorname{lnCH}_{4} \mathrm{c}$ and $\mathrm{lnCO}_{2} \mathrm{C}$ from different measuring equipment and AMS models (DeLaval and Lely A3 and A4 Astronauts) differed significantly. Traits $\operatorname{lnCH}_{4} \mathrm{c}$ and $\operatorname{lnCO}_{2} \mathrm{c}$ were further standardized within equipment and country to a mean of 0 and standard deviation of 1 , based on the findings of previous work combining GHG measuring equipment (Difford et al., 2016).

A 5-trait multi-trait analysis was performed to estimate the variance components and the heritability within each country; that is, DMI, FPCM, BW, $\operatorname{lnCH} 4$ c, and $\operatorname{lnCO}_{2}$ c. All analyses were performed using DMU version 6 (Madsen and Jensen, 2014). The model used in the Danish data set was as follows:

$$
\mathrm{y}_{i j k l m}=\mu+W_{i}+E T C_{j}+a_{l}+p e_{l}+e_{i j k l m},
$$

where $y_{i j k l m}$ is the trait of interest (DMI, BW, FPCM,

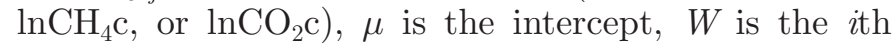
week of lactation, ETC is the $j$ th experiment by treatment contemporary group effect, $a_{l}$ is the random additive effect of the lth animal $\sim N D\left(0, \mathbf{A} \sigma_{a}^{2}\right)$, where $\mathbf{A}$ is the pedigree-derived numerator relationship matrix and $\sigma_{a}^{2}$ is the additive genetic variance, $p e$ is the permanent environmental effect distributed following $\sim N D\left(0, \mathbf{I} \sigma_{p e}^{2}\right)$, where $\sigma_{p e}^{2}$ is the permanent environmental variance and $e$ is the random residual $\sim N D\left(0, \mathbf{I} \sigma_{e}^{2}\right)$, where $\sigma_{e}^{2}$ is the residual variance and $\mathbf{I}$ represents identity matrices. For the feed intake traits (DMI, BW, and FPCM), the linear covariate age at first calving was significant and included in model [2] as a fixed regression.

For the Dutch data, it was necessary to place added restrictions on the residual covariance between $\operatorname{lnCH}_{4} \mathrm{c}$, $\operatorname{lnCO} 2 \mathrm{c}$, and DMI because these were recorded at different time points such that they were undefined:

$$
\begin{gathered}
\operatorname{Var}\left[\begin{array}{c}
\mathbf{a}_{\mathrm{DMI}} \\
\mathbf{a}_{\mathrm{GHG}}
\end{array}\right]=\left[\begin{array}{cc}
\mathbf{A} \sigma_{\mathrm{a}_{\mathrm{DMI}}^{2}}^{2} & \mathbf{A} \sigma_{\mathrm{aDMIaGHG}} \\
\mathbf{A} \sigma_{\mathrm{aGHGaDMI}} & \mathbf{A} \sigma_{\mathrm{a}_{\mathrm{GHG}}}^{2}
\end{array}\right], \\
\operatorname{Var}(p e)=P E=\left[\begin{array}{cc}
\sigma_{\mathrm{pe}_{\mathrm{DMI}}}^{2} & \sigma_{\mathrm{peDMIpeGHG}} \\
\sigma_{\mathrm{peGHGpDMI}} & \sigma_{\mathrm{pe}}^{2}
\end{array}\right], \\
\operatorname{Var}(e)=R=\left[\begin{array}{cc}
\sigma_{\mathrm{e}}^{2} & 0 \\
0 & \sigma_{\mathrm{e}_{\mathrm{DMI}}}^{2}
\end{array}\right] .
\end{gathered}
$$

For the Danish data set the models described in [2] above were then run without placing any restrictions on the covariances between $\operatorname{lnCH}_{4} \mathrm{c}, \operatorname{lnCO}_{2} \mathrm{c}$, and DMI.

The $5 \times 5$ (co)variance matrices estimated from the Danish and Dutch data sets were used to estimate genetic residual feed intake (RFIg) and phenotypic residual feed intake (RFIp; Kennedy et al., 1993; Shirali et al., 2017), in which matrices $\hat{\mathbf{G}}$ and $\hat{\mathbf{P}}$ are $5 \times 5$ additive genetic and phenotypic (co)variance matrices, respectively. Matrices $\hat{\mathbf{G}}$ and $\hat{\mathbf{P}}$ comprise feed intake $(\mathbf{F I})$ traits (i.e., DMI, FPCM, and BW) as well as GHG traits (i.e., $\operatorname{lnCH}_{4} \mathrm{c}$ and $\operatorname{lnCO}_{2} \mathrm{c}$ ). First, the multivariate genetic partial regression coefficients $\hat{b}_{g 1}$ and $\hat{b}_{g 2}$ of FPCM and BW on DMI were computed using genetic (co)variance matrices as follows: $\hat{b}_{g D M I|F P C M, B W|}=\hat{\mathbf{G}}_{D M I|F P C M, B W|} \hat{\mathbf{G}}_{F P C M, B W}^{-1}$, in which $\hat{\mathbf{G}}_{F P C M, B W}$ is a $2 \times 2$ genetic (co)variance matrix of FPCM and BW, and $\hat{\mathbf{G}}_{D M I|F P C M, B W|}$ is a $1 \times 2$ covariance vector of FPCM and BW on DMI, resulting in a 1 $\times 2$ vector of genetic partial regression coefficients. Similarly, the phenotypic partial regression coefficients $\hat{b}_{p 1}$ and $\hat{b}_{p 2}$ of FPCM and BW on DMI were estimated using the phenotypic (co)variance matrices as follows: 
$\hat{b}_{p D M I|F P C M, B W|}=\hat{\mathbf{P}}_{D M I|F P C M, B W|} \hat{\mathbf{P}}_{F P C M, B W}^{-1}$, in which $\hat{\mathbf{P}}_{F P C M, B W}$ is a $2 \times 2$ phenotypic (co)variance matrix of $\mathrm{FPCM}$ and BW, and $\hat{\mathbf{P}}_{D M I|F P C M, B W|}$ is a $1 \times 2$ covariance vector of FPCM and BW on DMI, resulting in a $1 \times 2$ vector of phenotypic partial regression coefficients used to estimated RFIp.

The RFIg, which has DMI genetically orthogonal of FPCM and BW, was estimated using $\hat{b}_{g 1}$ and $\hat{b}_{g 2}$; and the RFIp, which is DMI phenotypically orthogonal to FPCM and BW, was estimated using $\hat{b}_{p 1}$ and $\hat{b}_{p 2}$ in the following covariance function $\mathbf{B}$ :

$$
\mathbf{B}=\left[\begin{array}{ccccc}
\mathbf{I}_{D M I} & 0 & 0 & 0 & 0 \\
0 & \mathbf{I}_{F P C M} & 0 & 0 & 0 \\
0 & 0 & \mathbf{I}_{B W} & 0 & 0 \\
0 & 0 & 0 & \mathbf{I}_{C H_{4} c} & 0 \\
0 & 0 & 0 & 0 & \mathbf{I}_{C O 2 c} \\
\mathbf{I}_{D M I} & -\hat{b}_{g 1} & -\hat{b}_{g 2} & 0 & 0 \\
\mathbf{I}_{D M I} & -\hat{b}_{p 1} & -\hat{b}_{p 2} & 0 & 0
\end{array}\right] .
$$

Thus, $\mathbf{B}$ is a $7 \times 5$ identity matrix which is pre- and post-multiplied on the $5 \times 5 \hat{\mathbf{G}}$ and $\hat{\mathbf{P}}$ (co)variance matrices (i.e., BĜG' $\mathbf{B}^{\prime}$ ) to obtain a $7 \times 7$ genetic and phenotypic (co)variance matrices, including the newly computed RFIg, which has the favorable properties of being genetically uncorrelated with FPCM and BW; that is,

$$
\begin{gathered}
\hat{\mathbf{G}}_{R F I g|F P C M, B W|}=\hat{\mathbf{G}}_{D M I|F P C M, B W|} \\
-\hat{b}_{g D M I|F P C M, B W|} \hat{\mathbf{G}}_{F P C M, B W}=0,
\end{gathered}
$$

as well as RFIp, which has the less favorable properties of being phenotypically uncorrelated with FPCM and $\mathrm{BW}$; that is,

$$
\begin{aligned}
& \hat{\mathbf{P}}_{R F I p|F P C M, B W|}=\hat{\mathbf{P}}_{D M I|F P C M, B W|} \\
& -\hat{b}_{p D M I|F P C M, B W|} \hat{\mathbf{P}}_{F P C M, B W}=0 .
\end{aligned}
$$

Additionally, we considered a single-step phenotypic RFI (RFIss) to allow for modeling potential heterogeneity in phenotypic partial regression coefficients across different rations as recommended by Tempelman et al. (2015). The multi-trait model described in [2] above was rerun for all data sets, with changes to the DMI trait to include a fixed regression of FPCM and $\mathrm{BW}$ on DMI nested within the experiment by treatment contemporary $(\mathrm{ETC})$ effect $[\mathrm{ETC} \times(\mathrm{FPCM}, \mathrm{BW})]$. It was not possible to achieve model convergence between DMI and RFIss in any of the data sets tested, which prohibited us from making inferences on the genetic and phenotypic correlations between RFIss and DMI, RFIg, and RFIp. Correlations between EBV for RFIss, RFIg, RFIp, and DMI were used as proxies for genetic correlations.

\section{Selection Index Calculations}

Selection index theory was used to evaluate different recording strategies with FI and GHG trait combinations $(I)$ on the selection goals $(H)$ defined by DMI or RFI traits for bulls with daughter records by calculating selection accuracy $\left(r_{H, I}\right.$; Falconer and Mackay, 1996):

$$
r_{H, I}=\sqrt{\frac{\mathbf{b}^{\prime} \mathbf{P b}}{\mathbf{v}^{\prime} \mathbf{C v}}},
$$

where $r_{H, I}$ is the accuracy of the index, $\mathbf{P}$ is the $7 \times$ 7 matrix of phenotypic (co)variance among records of each trait (DMI, FPCM, BW, $\operatorname{lnCH}_{4} \mathrm{c}, \mathrm{LnCO}_{2} \mathrm{c}, \mathrm{RFIg}$, and RFIp); $\mathbf{v}$ is the $7 \times 1$ vector of relative economic values, and $\mathbf{C}$ is the genetic (co)variance matrix among traits to be improved. Here, $\mathbf{b}$ is the $7 \times 1$ vector of weighing factors for each of the records used in making selection decisions, calculated as $\mathbf{b}=\mathbf{P}^{-1} \mathbf{G v}$, where $\mathbf{G}$ is the genetic (co)variance matrix among all traits. To focus on recording strategies for feed efficiency traits or DMI, we arbitrarily assigned a value of 1 to the respective selection goal and 0 to all other traits in $\mathbf{v}$. Because there is a large disparity in the throughput of different traits, combinations were evaluated assuming bulls had 100 daughters with single average weekly records of $\ln \mathrm{CH}_{4} \mathrm{c}, \ln \mathrm{CO}_{2} \mathrm{c}, \mathrm{BW}$, and ECM (a realistic assumption in AMS herds) and 10 daughters with single weekly average DMI records (a realistic assumption with research and nucleus herds) using the Excel (Microsoft Corp., Redmond, WA) macro of van der Werf (2017). The above selection index calculations were also conducted between FPMC, BW, $\operatorname{lnCH}_{4} \mathrm{c}, \operatorname{lnCO}_{2} \mathrm{c}$, and RFIss to assess the relative merit of recording strategies for RFIss.

\section{RESULTS}

\section{Descriptive Statistics}

Descriptive statistics of FI- and GHG-related traits for DNK and NLD are shown in Table 2. The averages for FI-related traits were marginally higher for DNK than for NLD, with DMI being $19.5 \mathrm{~kg} / \mathrm{d}$ in DNK and $18.8 \mathrm{~kg} / \mathrm{d}$ in NLD, FPCM being $29.8 \mathrm{~kg} / \mathrm{d}$ in DNK and 
Table 2. Descriptive statistics of feed intake-related traits and greenhouse gas-related traits for each country

\begin{tabular}{|c|c|c|c|c|c|c|c|c|c|c|c|}
\hline Trait $^{1}$ & Unit & \multicolumn{5}{|c|}{ Denmark } & \multicolumn{5}{|c|}{ The Netherlands } \\
\hline FPCM & $\mathrm{kg} / \mathrm{d}$ & 23,398 & 29.8 & 5.8 & 3.0 & 54.0 & 11,736 & 28.2 & 5.2 & 2.9 & 44.1 \\
\hline BW & $\mathrm{kg}$ & 25,066 & 607.5 & 64.9 & 398.9 & 867.1 & 14,754 & 563.2 & 59.6 & 321.2 & 851.6 \\
\hline $\operatorname{lnCH}_{4} \mathrm{c}$ & $\ln (\mathrm{ppm})$ & 5,465 & 0 & 0.99 & -4.4 & 3.4 & 7,829 & 0 & 0.99 & -7.4 & 5.0 \\
\hline
\end{tabular}


carbon dioxide breath concentration.

$28.2 \mathrm{~kg} / \mathrm{d}$ in NLD, and BW being $607.5 \mathrm{~kg}$ in DNK and $563.2 \mathrm{~kg}$ in NLD. The GHG traits were likewise comparable between the countries before standardization, with $\mathrm{CH}_{4} \mathrm{c}$ higher in NLD $[5.9 \ln (\mathrm{ppm} / \mathrm{d})]$ than in DNK $[5.6 \ln (\mathrm{ppm} / \mathrm{d})]$. In contrast, $\mathrm{CO}_{2} \mathrm{c}$ was higher in DNK $[8.5 \ln (\mathrm{ppm} / \mathrm{d})]$ than in NLD $[8.3 \ln (\mathrm{ppm} / \mathrm{d})]$.

\section{Genetic Parameters}

The estimated genetic variances, heritability, and repeatability for Danish and Dutch data sets are shown in Table 3. In general, all estimates were markedly different between countries and higher for traits in DNK compared with NLD. The FI-related traits had higher heritability and repeatability than GHG-related traits.

FI-Related Traits. Estimated heritability for DMI was 0.43 in DNK and 0.16 in NLD, with SE ranging from 0.05 to 0.06 . The repeatability of DMI was more consistent: 0.65 in DNK and 0.55 in NLD. Heritability estimates for FPCM followed a similar pattern as DMI across data sets, with the highest estimate in DNK of 0.48 and 0.11 in NLD. Body weight was the most heritable trait in all data sets: 0.52 in DNK and 0.63 in NLD.
GHG-Related Traits. The $h^{2}$ estimates of $\operatorname{lnCH}_{4} \mathrm{c}$ and $\operatorname{lnCO}_{2} \mathrm{C}$ were more similar across data sets, compared with FI traits. The heritability of $\operatorname{lnCH}_{4} \mathrm{c}$ was 0.27 in DNK and 0.15 in NLD. Similarly, heritability of $\operatorname{lnCO}_{2} \mathrm{c}$ was 0.26 in DNK and 0.13 in NLD. The standard errors of heritabilities were high in both countries such that only $\operatorname{lnCH}_{4} \mathrm{C}$ in DNK did not include 0 in the $95 \%$ CI. Both $\operatorname{lnCH}_{4} \mathrm{c}$ and $\operatorname{lnCO}_{2} \mathrm{c}$ were highly repeatable in DNK (0.81 and 0.75) and in NLD (0.47 and 0.43$)$, respectively.

Feed Efficiency Traits. The genetic and phenotypic partial regression coefficients of FPCM and BW on DMI from the feed efficiency traits RFIg, RFIp, and RFIss are given in Table 4. The genetic partial regression coefficients for FPCM and BW on DMI differed between countries: 0.307 and 0.016 in DNK and 0.163 and 0.013 in NLD. In contrast, phenotypic regression coefficients were more similar across data sets. The phenotypic heterogeneous partial regression coefficients differed across feed rations over trials and seasons, with estimates ranging from 0.113 to 0.249 for FPCM on DMI and from 0.07 to 0.020 for BW on DMI. The $h^{2}$ of feed efficiency traits differed considerably across data sets and trait definitions. In general, $h^{2}$ was higher

Table 3. Estimated genetic $\left(\sigma_{a}^{2}\right)$ variances, heritability $\left(h^{2}\right)$ and repeatability of weekly averages $\left(t^{2}\right)$ with corresponding standard errors in parentheses from Denmark and the Netherlands

\begin{tabular}{|c|c|c|c|c|c|c|}
\hline Trait $^{1}$ & \multicolumn{3}{|c|}{ Denmark } & \multicolumn{3}{|c|}{ The Netherlands } \\
\hline FPCM & 18.31 & $0.48(0.02)$ & $0.81(0.01)$ & 1.97 & $0.11(0.03)$ & $0.68(0.01)$ \\
\hline BW & $1,695.9$ & $0.52(0.01)$ & $0.91(0.00)$ & 1,522 & $0.63(0.00)$ & $0.85(0.00)$ \\
\hline $\mathrm{CH}_{4} \mathrm{C}$ & 0.27 & $0.26(0.11)$ & $0.81(0.01)$ & 0.15 & $0.15(0.15)$ & $0.47(0.03)$ \\
\hline $\mathrm{CO}_{2} \mathrm{C}$ & 0.26 & $0.23(0.12)$ & $0.75(0.02)$ & 0.13 & $0.13(0.13)$ & $0.43(0.03)$ \\
\hline RFIss & 2.38 & $0.43(0.06)$ & $0.67(0.01)$ & 0.67 & $0.16(0.08)$ & $0.59(0.02)$ \\
\hline
\end{tabular}

${ }^{1} \mathrm{FPCM}=$ fat- and protein-corrected milk yield; $\mathrm{CH}_{4} \mathrm{c}=$ methane breath concentration; $\mathrm{CO}_{2} \mathrm{c}=$ carbon dioxide breath concentration; $\mathrm{RFIg}=$ genetic residual feed intake; RFIp = phenotypic residual feed intake; RFIss = single-step residual feed intake. 
Table 4. Estimated genetic partial regression coefficients for genetic residual feed intake and phenotypic partial regression coefficients for phenotypic residual feed intake and single-step residual feed intake (RFIss) of fat- and protein-corrected milk (FPCM) and BW on DMI

\begin{tabular}{lccccc}
\hline & \multicolumn{2}{c}{ Denmark } & & \multicolumn{2}{c}{ The Netherlands } \\
\cline { 2 - 3 } \cline { 5 - 6 } Trait $^{1}$ & DMI|FPCM & DMI $\mid \mathrm{BW}$ & & DMI $\mid \mathrm{FPCM}$ & DMI $\mid \mathrm{BW}$ \\
\hline RFIg & 0.3069 & 0.0162 & & 0.1626 & 0.0129 \\
RFIp $_{\text {RFIss }}^{2}$ & 0.2162 & 0.0137 & & 0.2731 & 0.0115 \\
l $^{2}$ & $0.113 \pm 0.02$ & $0.008 \pm 0.002$ & & $0.249 \pm 0.02$ & $0.020 \pm 0.001$ \\
\hline
\end{tabular}

${ }^{1}$ Feed efficiency restricted indices: genetic residual feed intake (RFIg), phenotypic residual feed intake (RFIp), single-step residual feed intake (RFIss).

${ }^{2}$ Range of estimated partial regression coefficients for different experimental rations (estimate $\pm \mathrm{SE}$ ).

in DNK than NLD, and $h^{2}$ was highest for RFIss and RFIp, followed by RFIg across countries. Finally, RFIss (0.43 in DNK and 0.16 in NLD) was higher than RFIp (0.21 in DNK and 0.10 in NLD) and RFIg (0.14 in DNK and 0.09 in NLD) (Table 3).

\section{Genetic and Phenotypic Correlations}

Genetic and phenotypic correlations between FIrelated traits and GHG-related traits within DNK and NLD data sets are presented in Table 5. In general, the genetic correlations $\left(\mathbf{r}_{\mathrm{g}}\right)$ between FI and GHG traits were inconsistent across data sets, as discussed below. Furthermore, the standard errors of genetic correlations were quite variable, ranging from 0.00 to 0.44 , and must be considered carefully during interpretation.

FI-Related Traits. Dry matter intake was moderately to highly genetically and phenotypically correlated with FPCM and BW, albeit inconsistently across countries. Genetic correlations for FPCM were $0.83 \pm$ 0.04 in DNK and $0.47 \pm 0.28$ in NLD. Genetic correlations between DMI and BW were also different across data sets: $0.45 \pm 0.08$ in DNK and $0.71 \pm 0.16$ in NLD. Genetic correlations between FPCM and BW ranged

Table 5. Genetic (below diagonal) and phenotypic (above diagonal) correlations (SE in parentheses) between feed intake-related traits, ${ }^{1}$ greenhouse gas-related traits, ${ }^{2}$ and feed efficiency restricted indices ${ }^{3}$ for Denmark and the Netherlands

\begin{tabular}{|c|c|c|c|c|c|c|c|c|}
\hline Trait & \multicolumn{8}{|c|}{ Denmark } \\
\hline DMI & & $0.59(0.02)$ & $0.35(0.03)$ & $0.54(0.02)$ & $0.75(0.01)$ & $\mathrm{NC}^{4}$ & $0.33(0.04)$ & $0.25(0.04)$ \\
\hline BW & $0.45(0.08)$ & $0.06(0.11)$ & & $-0.09(0.02)$ & $0.00(0.02)$ & $0.32(0.03)$ & $0.12(0.05)$ & $0.08(0.05)$ \\
\hline RFIg & $0.38(0.13)$ & $0.00(0.17)$ & $0.00(0.16)$ & & $0.96(0.00)$ & $\mathrm{NE}^{5}$ & $0.07(0.04)$ & $0.12(0.04)$ \\
\hline RFIp & $0.79(0.06)$ & $0.48(0.13)$ & $0.18(0.13)$ & $0.86(0.04)$ & & $\mathrm{NE}$ & $0.16(0.04)$ & $0.17(0.04)$ \\
\hline $\operatorname{lnCO} C_{2} \mathrm{c}$ & \multicolumn{8}{|c|}{ The Netherlands } \\
\hline DMI & & $0.59(0.02)$ & $0.35(0.03)$ & $0.89(0.01)$ & $0.77(0.01)$ & $\mathrm{NC}$ & $0.01(0.07)$ & $-0.01(0.07)$ \\
\hline FPCM & $0.47(0.28)$ & & $0.18(0.03)$ & $0.27(0.02)$ & $0.00(0.03)$ & $0.62(0.21)$ & $0.10(0.03)$ & $0.10(0.03)$ \\
\hline BW & $0.71(0.16)$ & $0.29(0.23)$ & & $0.01(0.03)$ & $0.00(0.03)$ & $0.33(0.36)$ & $0.06(0.04)$ & $0.08(0.04)$ \\
\hline
\end{tabular}

${ }^{1}$ Feed intake-related traits: DMI, fat- and protein-corrected milk yield (FPCM), and BW.

${ }^{2}$ Greenhouse gas-related traits: natural logarithms of methane $\left(\operatorname{lnCH}_{4} \mathrm{c}\right)$ and carbon dioxide $\left(\operatorname{lnCO}_{2} \mathrm{c}\right)$ breath concentrations.

${ }^{3}$ Feed efficiency restricted indices: genetic residual feed intake (RFIg), phenotypic residual feed intake (RFIp), single-step residual feed intake (RFIss).

${ }^{4} \mathrm{NC}=$ not converged.

${ }^{5} \mathrm{NE}=$ not able to be estimated.

${ }^{6}$ Correlations between EBV as proxy for genetic correlations. 
from close to zero $(0.06 \pm 0.11)$ in DNK to lowly positive $(0.29 \pm 0.23)$ in NLD, and estimates of 0 fell well within the $95 \%$ CI. The phenotypic correlations between FPCM and BW were very similar, ranging from $0.08 \pm 0.02$ in DNK to $0.18 \pm 0.03$ in NLD.

GHG-Related Traits. The $\mathrm{r}_{\mathrm{g}}$ between GHG traits and FI traits were very different across data sets. Dry matter intake was strongly genetically correlated with $\operatorname{lnCH}_{4} \mathrm{C}$ in DNK $(0.60 \pm 0.13)$ but close to zero in NLD $(-0.09 \pm 0.38)$. Similarly, for $\operatorname{lnCO}_{2} \mathrm{c}$, estimates ranged from 0.42 in DNK to -0.08 in NLD, with large standard errors similar to those for $\operatorname{lnCH}_{4} \mathrm{c}$. The GHG traits also showed similar inconsistency patterns for $r_{\mathrm{g}}$ with FPCM and BW in both countries, where $r_{g}$ with FPCM ranged from 0.20 to 0.61 and with $\mathrm{BW}$ from -0.08 to 0.34. The genetic and phenotypic correlations between $\operatorname{lnCH} 4 \mathrm{c}$ and $\operatorname{lnCO}_{2} \mathrm{c}$ were, however, consistently very high across countries, with $\mathrm{r}_{\mathrm{g}}$ ranging from $0.96-0.97$.

Feed Efficiency Traits. The $\mathrm{r}_{\mathrm{g}}$ between feed efficiency traits and components traits (DMI, FPCM, and BW) were highly varied across countries and trait definitions of RFI (Table 5). In general, RFI traits were strongly and positively genetically correlated with DMI; however, the range of estimates was large $\left(\mathrm{r}_{\mathrm{g}}=\right.$ 0.38-0.79) and even higher for the correlation between EBV for DMI and RFIss as a proxy for $\mathrm{r}_{\mathrm{g}}(0.95)$. By definition, RFIp was phenotypically uncorrelated with component traits FPCM and BW in both countries, and RFIg was genetically uncorrelated with FPCM and BW in both countries; RFIss was both genetically and phenotypically correlated with FPCM and BW. Despite very different partial regression coefficients, the $\mathrm{r}_{\mathrm{g}}$ between the 2 restricted selection index phenotypes RFIp and RFIg were consistently close to unity: $r_{\mathrm{g}}=$ $0.86 \pm 0.04$ in DNK and $r_{g}=0.96 \pm 0.02$ in NLD. It was not possible to estimate $\mathrm{r}_{\mathrm{g}}$ between RFIp and RFIg with RFIss, but the correlations between their EBV as a proxy, were moderate with RFIg (0.46-0.67) and high with RFIp (0.66-0.82) in both countries.

The $r_{g}$ between feed efficiency traits and GHG traits were inconsistent across countries and trait definitions of feed efficiency. In Denmark, $\mathrm{lnCH}_{4} \mathrm{c}$ was moderate to strongly positively genetically correlated with feed efficiency traits RFIg $\left(r_{g}=0.42 \pm 0.23\right)$, RFIp $\left(r_{g}=0.59 \pm\right.$ $0.19)$, and RFIss $\left(r_{\mathrm{g}}=0.69 \pm 0.15\right)$. In the Netherlands, however, $\mathrm{lnCH}_{4} \mathrm{c}$ was negatively correlated with RFIg $\left(\mathrm{r}_{\mathrm{g}}=-0.55 \pm 0.41\right)$ and RFIp $\left(\mathrm{r}_{\mathrm{g}}=-0.69 \pm 0.38\right)$, but positively correlated with RFIss $\left(\mathrm{r}_{\mathrm{g}}=0.46 \pm 0.36\right)$, although the standard errors were large. The genetic correlations between $\operatorname{lnCO}_{2} \mathrm{c}$ and feed efficiency traits were very similar to that of $\operatorname{lnCH}_{4} \mathrm{c}$ across countries and feed efficiency trait definitions.

\section{Prediction Accuracy of Selection Indices for DMI and Feed Efficiency}

The accuracy of bull selection goals for DMI and feed efficiency traits based on the DNK and NLD estimated

Table 6. Selection accuracies for bulls for DMI, genetic residual feed intake (RFIg), phenotypic residual feed intake (RFIp), and single-step interaction phenotypic residual feed intake (RFIss) using differing recording schemes with feed intake-related traits $^{1}$ and greenhouse gas-related traits ${ }^{2}$

\begin{tabular}{|c|c|c|c|c|}
\hline Selection index accuracy ${ }^{3}$ & DMI & RFIg & RFIp & RFIss \\
\hline \multicolumn{5}{|l|}{ Denmark } \\
\hline $\mathrm{DMI}_{10}$ & 0.75 & 0.18 & 0.57 & $\mathrm{NE}^{4}$ \\
\hline $\operatorname{lnCH}_{4} \mathrm{c}_{100}+\ln \mathrm{CO}_{2} \mathrm{c}_{100}$ & 0.54 & 0.51 & 0.48 & 0.78 \\
\hline $\mathrm{BW}_{100}+\mathrm{FPCM}_{100}$ & 0.77 & 0 & 0.48 & 0.70 \\
\hline $\mathrm{DMI}_{10}+\operatorname{lnCH}_{4} \mathrm{c}_{100}+\ln \mathrm{CO}_{2} \mathrm{c}_{100}$ & 0.79 & 0.50 & 0.70 & NE \\
\hline $\mathrm{DMI}_{10}+\mathrm{BW}_{100}+\mathrm{FPCM}_{100}$ & 0.85 & 0.21 & 0.59 & $\mathrm{NE}$ \\
\hline $\mathrm{BW}_{100}+\mathrm{FPCM}_{100}+\operatorname{lnCH}_{4} \mathrm{c}_{100}+\operatorname{lnCO}_{2} \mathrm{c}_{100}$ & 0.97 & 0.89 & 0.92 & 0.94 \\
\hline $\mathrm{DMI}_{10}+\mathrm{BW}_{100}+\mathrm{FPCM}_{100}+\operatorname{lnCH}_{4} \mathrm{c}_{100}+\ln \mathrm{CO}_{2} \mathrm{c}_{100}$ & 0.97 & 0.89 & 0.93 & $\mathrm{NE}$ \\
\hline \multicolumn{5}{|l|}{ The Netherlands } \\
\hline $\mathrm{DMI}_{10}$ & 0.65 & 0.37 & 0.30 & $\mathrm{NE}$ \\
\hline $\operatorname{lnCH}_{4} \mathrm{c}_{100}+\ln \mathrm{CO}_{2} \mathrm{c}_{100}$ & 0.07 & 0.46 & 0.57 & 0.35 \\
\hline $\mathrm{BW}_{100}+\mathrm{FPCM}_{100}$ & 0.71 & 0 & 0.25 & 0.62 \\
\hline $\mathrm{DMI}_{10}+\operatorname{lnCH}_{4} \mathrm{c}_{100}+\ln \mathrm{CO}_{2} \mathrm{c}_{100}$ & 0.66 & 0.57 & 0.63 & NE \\
\hline $\mathrm{DMI}_{10}+\mathrm{BW}_{100}+\mathrm{FPCM}_{100}$ & 0.79 & 0.42 & 0.47 & $\mathrm{NE}$ \\
\hline $\mathrm{BW}_{100}+\mathrm{FPCM}_{100}+\operatorname{lnCH}_{4} \mathrm{c}_{100}+\ln \mathrm{CO}_{2} \mathrm{c}_{100}$ & 0.78 & 0.53 & 0.58 & 0.64 \\
\hline 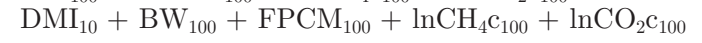 & 0.83 & 0.60 & 0.63 & NE \\
\hline
\end{tabular}

${ }^{1}$ Feed intake-related traits: DMI, fat- and protein-corrected milk yield (FPCM), and BW.

${ }^{2}$ Greenhouse gas-related traits: natural logarithms of methane $\left(\operatorname{lnCH}_{4} \mathrm{c}\right)$ and carbon dioxide $\left(\operatorname{lnCO}_{2} \mathrm{c}\right)$ breath concentrations.

${ }^{3}$ Subscripts denote the number of daughters with a single weekly average record for a given trait within a selection index.

${ }^{4} \mathrm{NE}=$ not able to be estimated. 
$\mathbf{G}$ and $\mathbf{P}$ (co)variance matrices for several recording strategies using different combinations of FI and GHG traits are presented in Table 6. For DMI and feed efficiency traits, including the DMI daughter records gave higher accuracies than indices that included only GHG or FPCM and BW, and the highest accuracies were achieved when all sources of information were included.

For DMI, in both countries, bulls having 100 daughters with $\operatorname{lnCH}_{4} \mathrm{c}$ and $\operatorname{lnCO}_{2} \mathrm{c}$ alone gave the lowest accuracies for all recording scenarios. However, having 100 daughters with BW, FPCM, $\operatorname{lnCH}_{4} \mathrm{c}$, and $\operatorname{lnCO}_{2} \mathrm{C}$ gave higher accuracies $(0.97 \mathrm{DNK}$ and $0.78 \mathrm{NLD})$ than having 10 daughters with DMI records $(0.75$ DNK and $0.65 \mathrm{NLD}$ ) and comparable accuracies to the scenario including all traits (0.97 DNK, 0.83 NLD). For RFIg and RFIp, bulls having $\operatorname{lnCH}_{4} \mathrm{c}$ and $\operatorname{lnCO}_{2} \mathrm{c}$ on 100 daughters gave higher or comparable accuracies (0.480.51 in DNK, 0.46-0.57 in NLD) than having 10 daughters with DMI records (0.18-0.57 in DNK, 0.30-0.37 in NLD). For RFIg, bulls with 100 daughters having FPCM and BW records gave accuracies of 0 , whereas for RFIp, accuracies were lower or comparable to the GHG indices (0.48 in DNK and 0.25 in NLD). Models including RFIss and DMI did not converge, so we could not assess the use of DMI on RFIss selection index accuracies; however, having 100 daughters for FPCM, $\mathrm{BW}, \operatorname{lnCH}_{4} \mathrm{c}$, and $\ln \mathrm{CO}_{2} \mathrm{c}$ resulted in high accuracies across countries (0.94 in DNK, 0.64 in NLD).

\section{DISCUSSION}

\section{Genetic Parameters}

FI-Related Traits. Investigations into the FIrelated traits DMI, FPCM, and BW have been an area of intense research in DNK and NLD, with both being members of international collaborative consortia such as the global dry matter initiative (Berry et al., 2014). The heritability estimated for DMI in DNK (0.43) was slightly higher than reported previously for Nordic Holsteins $(0.20-0.40)$ by Li et al. (2016). However, Li et al. (2016) estimated $h^{2}$ for 1 to $24 \mathrm{wk}$ of lactation, with an increasing trend from 0.20 to 0.40 , whereas we reported entire lactation $h^{2}$ from wk 1 to 44 . Similarly, the $h^{2}$ estimate for DMI in NLD was lower than the range of reported values from previous studies (0.15-0.41; Koenen and Veerkamp, 1998; Vallimont et al., 2010). However, DMI data in NLD were recorded in lactation wk 1 to 10 for most cows (77\%) that calved since 2000 . Thus, for both countries, restricting the use of older historical data and differences in the length of recording over lactation has resulted in changes in heritability estimates for DMI compared with previous studies in each country. In the present study, parameters were estimated in repeatability animal models over the course of the entire first lactation, recognizing that previous findings from both populations demonstrate that the genetic parameters of DMI, FPCM, and BW change over the course of lactation (Manzanilla Pech et al., 2014; Li et al., 2016).

The $h^{2}$ estimate for FPCM in DNK $\left(h^{2}=0.48\right)$ was larger than those reported for ECM in DNK (0.27-0.39; Søndergaard et al., 2002; Lassen and Løvendahl, 2016). This could be due to the differences in temporal distribution of data through years and through lactation as discussed above for DMI. It is also important to recognize that the trait definitions for ECM and FPCM differ, as different linear combinations of milk, fat, and protein yields, with FPCM scaled to $1.9 \% \mathrm{MY}$, $64.7 \%$ fat yield, and $33.4 \%$ protein yield (CVB, 2008), and ECM scaled to $1.2 \% \mathrm{MY}, 60.5 \%$ fat yield, and $38.2 \%$ protein yield (Sjaunja et al., 1991). The choice of FPCM was driven by the need to make findings of this study comparable to international research efforts for GHG mitigation (FAO, 2010). The $h^{2}$ estimate for FPCM in NLD was 0.11 , well below the range of previous findings in NLD (0.22-0.43; Manzanilla Pech et al., 2014). The lower heritability could be due to using cows that have calved since 2000 instead of 1990, as was reported by Manzanilla Pech et al. (2014). It is also important to note that heritability estimates were generally lower in NLD than in DNK, and lower than previously reported NLD estimates. The NLD data set included cows from 4 research herds and an additional 10 commercial AMS milking herds, which may have contributed to increased residual variation and reduced heritability, whereas only a single research herd and 2 commercial AMS milking herds were included in DNK. Last, the heritability estimates for BW were within the reported ranges in DNK for multiparous Nordic cattle breeds (0.52-0.77; Søndergaard et al., 2002; Sloniewski et al., 2005) and primiparous Dutch Holstein Friesian cows (0.22-0.74; Koenen and Veerkamp, 1998; Manzanilla Pech et al., 2014).

GHG-Related Traits. The heritability estimates of $\ln \mathrm{CH}_{4} \mathrm{c}$ and $\operatorname{lnCO}_{2} \mathrm{c}$ were consistently moderate across data sets with $h^{2}$ of 0.27 and 0.26 in DNK and 0.15 and 0.13 in NLD, respectively. These estimates are larger than those reported for primi- and multiparous Dutch Holsteins Friesians in commercial herds: $\operatorname{lnCH}_{4} \mathrm{c}\left(h^{2}=\right.$ $0.11 \pm 0.02)$ and $\operatorname{lnCO}_{2} \mathrm{c}\left(h^{2}=0.12 \pm 0.02\right.$; van Engelen et al., 2018), of which the primiparous cows were part of this study. However, the estimates of van Engelen et al. (2018) were based on mean $\operatorname{lnCH}_{4} \mathrm{c}$ and $\operatorname{lnCO}_{2} \mathrm{c}$ per milking, whereas we used an average per week of lactation and thus had many more repeated measures 
per cow, which is an effective error reduction technique with sniffers and a benefit of high-throughput measures (Difford et al., 2016). Although $\operatorname{lnCH}_{4} \mathrm{c}$ and $\operatorname{lnCO}_{2} \mathrm{c}$ are short-term breath concentration measures, the $\mathrm{h}^{2}$ estimates are comparable to that of 24 -h total mass flux $\mathrm{CH}_{4}$ production from respiration chambers in over 1,000 growing Aberdeen Angus $\left(h^{2}=0.22 \pm\right.$ 0.06; Donoghue et al., 2016), 1,225 dual-purpose mixed and composite sheep $\left(h^{2}=0.29 \pm 0.05\right)$ using portable accumulation chambers (Pinares-Patiño et al., 2013), and lambs in respiration chambers $\left(h^{2}=0.23 \pm 0.04\right.$; Jonker et al., 2018).

\section{Genetic Correlations}

FI-Related Traits. Genetic correlations between FPCM and BW were close to zero in both countries, ranging from low $(0.06 \pm 0.11)$ in DNK to moderate $(0.29 \pm 0.23)$ in NLD, following the large range of estimates in literature (ranges reported in square brackets; ECM and FPCM, $\mathrm{r}_{\mathrm{g}}=[-0.36,0.60]$; Manzanilla Pech et al., 2014; Lassen and Løvendahl, 2016; Lu et al., 2017).

Dry matter intake was differentially genetically correlated with FPCM and BW in DNK and NLD. In DNK, DMI was highly genetically correlated with FPCM $\left(r_{g}=0.83 \pm 0.04\right)$, and moderately correlated

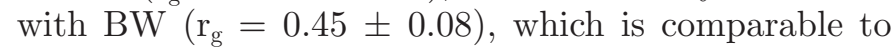
the ranges reported for Nordic Holsteins between DMI and ECM $\left(\mathrm{r}_{\mathrm{g}}=[0.24,0.80]\right)$ as well as DMI and BW $\left(\mathrm{r}_{\mathrm{g}}=[0.3,0.7] ;\right.$ Li et al., 2018). Conversely, in NLD, DMI was moderately correlated with FPCM $\left(\mathrm{r}_{\mathrm{g}}=0.47\right.$ $\pm 0.28)$ and highly correlated with $\mathrm{BW}(0.71 \pm 0.16)$, which are lower than full-lactation repeatability models in NLD of 0.86 for FPCM and 0.45 of BW with DMI (Manzanilla Pech et al., 2014). However, most DMI records in NLD were recorded within the first 70 DIM, and our genetic correlation estimates are comparable to the ranges reported from random regression models from 1 to 70 DIM for DMI and FPCM $\left(\mathrm{r}_{\mathrm{g}}=[-0.55\right.$, $0.8])$ and DMI and BW $\left(\mathrm{r}_{\mathrm{g}}=[0.38,0.6]\right.$; Manzanilla Pech et al., 2014).

The present NLD data differ from that of Manzanilla Pech et al. (2014), because only cows calving since 2000 were retained to limit genetic heterogeneity due to selection over time. The recent recording strategy in NLD includes DMI recording for the first 1 to $10 \mathrm{wk}$ of lactation, and continuous recordings of FPCM and BW are made through wk 1 to 44 . The relative differences in genetic correlations for FI traits between DNK and NLD as well as the differences between previously reported genetic correlations in NLD suggest lactation stage genetic heterogeneity in FI-related traits. Manza- nilla Pech et al. (2014) reported patterns of heterogeneity between the first 48 DIM ( $7 \mathrm{wk}$ ) of lactation and the remainder of lactation for DMI, FPCM, and BW. Similarly, genetic heterogeneity was observed between the first 8 wk of lactation and the remaining weeks of lactation in FI-related traits in 3 Nordic dairy cattle breeds (Li et al., 2018), suggesting that the genetic relationships between FI-related traits and feed efficiency traits can vary greatly between early and mid to late lactation (Li et al., 2017; Løvendahl et al., 2018).

GHG-Related Traits. These are the first reported genetic correlations for breath gas concentration measures and FI-related traits, which makes comparisons with the literature challenging. Recently, genetic correlations have been reported for $\mathrm{CH}_{4}$ production using the $\mathrm{SF}_{6}$ method in 314 multiparous Australian Holsteins under grazing conditions (Breider et al., 2018). The genetic correlations between $\mathrm{CH}_{4} \mathrm{c}$ and mass flux $\mathrm{CH}_{4}$ production is not currently known and is needed to assess the merit of $\mathrm{CH}_{4} \mathrm{C}$ as an indicator trait for $\mathrm{CH}_{4}$ production. The phenotypic correlation $\left(\mathrm{r}_{\mathrm{p}}\right)$ between $\mathrm{CH}_{4} \mathrm{c}$ and $\mathrm{CH}_{4}$ production is unlikely to be unity, based on $\mathrm{R}^{2}$ values from comparisons using the artificial reference cow, GreenFeed (C-Lock Inc., Rapid City, SD), or sniffers (Huhtanen et al., 2015; Difford et al., 2018; $\mathrm{Wu}$ et al., 2018). However, it is positive and in the range of 0.29 to 0.97 , depending on extraneous factors such as cow muzzle position from the sniffer inlet and wind speed (Huhtanen et al., 2015; Wu et al., 2018). Moreover, the correlation between $\mathrm{CH}_{4}$ production and FI-related traits can provide some insight into the expected nature of $\mathrm{CH}_{4} \mathrm{c}$ and $\mathrm{FI}$ traits. Breider et al. (2018) found $\mathrm{CH}_{4}$ production to be moderately genetically correlated with DMI $\left(\mathrm{r}_{\mathrm{g}}=0.34 \pm 0.22\right)$, MY $\left(\mathrm{r}_{\mathrm{g}}\right.$ $=0.26 \pm 0.27)$, and BW $\left(\mathrm{r}_{\mathrm{g}}=0.42 \pm 0.16\right)$. Similarly, Lassen and Løvendahl (2016) reported genetic correlations between $\mathrm{CH}_{4}$ production and FPCM $\left(\mathrm{r}_{\mathrm{g}}=0.43 \pm\right.$ $0.10)$ and $\mathrm{BW}\left(\mathrm{r}_{\mathrm{g}}=-0.18 \pm 0.08\right)$, suggesting that the genetic correlations we report for $\mathrm{CH}_{4} \mathrm{C}$ and FI-related traits are within the ranges reported in literature.

Interestingly, genetic and phenotypic correlations between $\operatorname{lnCH}_{4} \mathrm{c}$ and $\operatorname{lnCO}_{2} \mathrm{c}$ were close to unity $(0.97$ and 0.96, respectively, in DNK, and 0.96 and 0.87 in NLD). Studies using RC have reported phenotypic correlations as high as 0.96 between $\mathrm{CH}_{4}$ production and $\mathrm{CO}_{2}$ production (Aubry and Yan, 2015). Jonker et al. (2018) reported genetic parameters for lambs in RC and found a similarly high genetic correlation of 0.84 \pm 0.04 between $\mathrm{CH}_{4}$ production and $\mathrm{CO}_{2}$ production. This would suggest the relationship between the 2 gases is highly conserved. Some prediction equations for $\mathrm{CH}_{4}$ production are premised on the relationship between $\mathrm{CH}_{4}$ and $\mathrm{CO}_{2}$ (Madsen et al., 2010). Validation of these 
high correlations between $\mathrm{CH}_{4}$ and $\mathrm{CO}_{2}$ are needed across multiple methods of gas measurement.

\section{Feed Efficiency Traits}

Because feed efficiency is not directly observable and is defined as feed intake conditional on a combination of production traits or energy sinks (component traits), it is dependent on the genetic relationships between these traits. The genetic and phenotypic correlations between DMI and components traits have previously been shown to be influenced by lactation stage heterogeneity (Manzanilla Pech et al., 2014; Li et al., 2018) or possible genotype by environment interactions due to different research stations and energy density of rations (Tempelman et al., 2015; Lu et al., 2017; Yao et al., 2017). There are a multitude of trait definitions in literature with a wide range of heritability estimates $\left(h^{2}=0-0.38\right.$; Berry and Crowley, 2013), the definitions most closely aligned to breeding practices are the restricted selection index approaches (RFIg and RFIp; Kennedy et al., 1993; Veerkamp et al., 1995). However, these approaches assume fixed and estimable genetic or phenotypic partial regression coefficients between DMI and components traits and do not directly account for heterogeneity in partial regression coefficients due to lactation stage or different energy densities of rations. Tempelman et al. (2015) proposed the use of RFIss, allowing for heterogeneity in phenotypic partial regression coefficients due to different energy densities in rations at different research stations, this was later extended to genetic partial regression coefficients in a Bayesian approach (Lu et al., 2017). Currently, no definitions of RFI account for both heterogeneity in lactation stage and energy density of rations.

The current study estimated RFIg, RFIp, and RFIss, which showed a trend of increasing heritability toward that of DMI (RFIg $=0.14$, RFIp $=0.21$, and RFIss $=$ 0.43 in DNK; RFIg $=0.09$, RFIp $=0.10$ and RFIss $=$ 0.16 in NLD), although in NLD, only the RFIss estimate was significant. Similarly, RFIg has been reported to be smaller than RFIp (Veerkamp et al., 1995; Shirali et al., 2018), which, in turn, has been reported to be smaller than RFIss (Tempelman et al., 2015).

The trend of heritability among RFI traits appears to follow the trend of the magnitude of genetic relationships with DMI and component traits. By defining RFIg, it was possible to express DMI as genetically independent of both traits, which resulted in the lowest feed efficiency $h^{2}$ estimate. Thus, despite very different genetic (co)variances between the 2 countries, it was feasible to identify cows that genetically require less DMI without affecting changes to FPCM and BW. However, the standard errors of these correlations were still large, and higher numbers of cows are needed to estimate these parameters with higher levels of certainty needed for implementation. Interestingly, the phenotypic correlations between FI-related traits were very similar in both countries and defining RFIp similarly resulted in phenotypic correlations with FPCM and BW of zero. However, nonzero genetic correlations between RFIp and FPCM and BW remain in both countries (FPCM $\mathrm{r}_{\mathrm{g}}=0.48 \pm 0.13, \mathrm{BW} \mathrm{r}_{\mathrm{g}}=0.18 \pm 0.13$ in DNK; FPCM $\mathrm{r}_{\mathrm{g}}=-0.26 \pm 0.41, \mathrm{BW} \mathrm{r}_{\mathrm{g}}=0.02 \pm 0.26$ in NLD). The genetic correlations between RFIg and RFIp were strongly positive in both countries $(0.86 \pm 0.04$ in DNK and $0.96 \pm 0.02$ in NLD) in agreement with $\mathrm{Lu}$ et al. (2017). Shirali et al. (2018) estimated RFIg, RFIp, and FCR in 3,724 growing pigs and found a genetic correlation of $0.92 \pm 0.04$ between RFIg and RFIp and $0.89 \pm$ 0.04 between RFIg and FCR. Although direct and correlated responses of selection for RFIg were consistent, direct and correlated responses to selection for RFIp and FCR were inconsistent, and unexpected responses in feed intake, $\mathrm{ADG}$, and lean meat percentage were observed, suggesting nonequivalence between RFIp and RFIg (Shirali et al., 2018).

To test for heterogeneity due to energy density changes in rations over seasons and from different research trials, we estimated RFIss (Tempelman et al., 2015). Despite significant interaction terms between ETC and partial regression coefficients of FPCM and BW on DMI in both countries, the $h^{2}$ and additive genetic variation estimates were the same or very close to that of DMI, with similar genetic and phenotypic correlations to component traits. It is challenging to assess the goodness of fit and genetic equivalence or lack thereof for RFIss and DMI, because models including DMI and RFIss failed to converge in both countries, preventing further estimation of matrices needed for the computation of RFIg and RFIp and their correlations with RFIss. This is a limitation of the 2-step and single-step RFI methodologies previously reported (Tempelman et al., 2015). We computed the correlation between EBV for RFIss, DMI, RFIg, and RFIp as a proxy to genetic correlations and found very similar correlations between RFIss with RFIg and RFIp as were found for DMI with RFIg and RFIp. The largest discrepancy was in correlations between EBV for DMI and RFIss in the 2 countries. In DNK, it was strong and positive (0.90), indicating minimal heterogeneity due to different energy densities of rations. However, the correlation between DMI and RFIss in NLD was substantially lower $(0.50)$, indicating that heterogeneity due to different energy densities of diets had an effect in NLD. In the presence of heterogeneity between 
component traits and DMI, it is necessary to estimate either RFIss (phenotypic adjustment; Tempelman et al., 2015) or RFIg using hierarchical Bayesian multitrait models (Lu et al., 2017) or subset the data further and make use of multitrait genotype by environment interactions models defined by diet.

\section{Relationship Between GHG Traits and Feed Efficiency}

Both GHG traits had moderate to high genetic correlations with all feed efficiency traits in both countries, and the magnitude of the genetic correlations increased from 0.42 with RFIg in DNK to -0.69 with RFIp in NLD. Crucially, the sign of genetic correlations between GHG traits and feed efficiency traits differed between countries for RFIg and RFIp, being positive in DNK and negative in NLD. Furthermore, the sign of genetic correlations for RFIss and GHG traits was positive in both countries. These results highlight the complexity of the relationships between feed efficiency traits and GHG traits in the presence of possible lactation stage and dietary heterogeneity.

The relationship between $\mathrm{CH}_{4}$ emission and feed efficiency is contentious, with inconsistent results between RFIp and $\mathrm{CH}_{4}$ production. Positive phenotypic correlations $\left(r_{p}=0.10-0.56\right)$ between residual energy intake and $\mathrm{CH}_{4}$ production predicted from energy intake and the ratio of $\mathrm{CH}_{4} \mathrm{c} / \mathrm{CO}_{2} \mathrm{c}$ from sniffers in concentrate feeders were reported for 412 lactating Nordic red cattle (Negussie et al., 2014). Similarly, a study using the GreenFeed system found efficient RFIp groups to have significantly reduced $\mathrm{DMI}, \mathrm{CH}_{4}$, and $\mathrm{CO}_{2}$ production compared with inefficient RFIp (Hailemariam et al., 2016). All of these methods require supplemented concentrate to attract the cow to the instrument and, in the case of sniffers installed in AMS, concentrate supplementation is based on individual milk production. In contradiction, a separate study in respiration chambers found efficient RFIp groups to have reduced DMI but increased $\mathrm{CH}_{4}$ and $\mathrm{CO}_{2}$ production compared with inefficient RFIp groups (Olijhoek et al., 2018). To date, only a single genetic correlation $\left(r_{g}=0.72\right)$ between $\mathrm{CH}_{4}$ production predicted from gross energy intake and phenotypic RFI has been reported (de Haas et al., 2011). Breider et al. (2018) investigated the responses to selection in DMI, MY, BW, and $\mathrm{CH}_{4}$ production from $\mathrm{SF}_{6}$, using restricted selection indices in Australian Holsteins on pasture. However, the index for reducing DMI and restricting MY and BW (RFIg) showed a correlated increase in $\mathrm{CH}_{4}$ production, indicating that efficient RFIg cows have higher $\mathrm{CH}_{4}$ production. Using the estimated parameters from Breider et al. (2018) and the methods described in Kennedy et al. (1993), it is possible to estimate the genetic correlation between $\mathrm{RFIg}$ and $\mathrm{CH}_{4}$ production, which was small $\left(r_{g}=-0.004\right.$; Breider et al., 2018).

Inconsistencies in identifying genetic correlations between GHG traits and feed efficiency in the aforementioned studies could be due to differences in environment and diet (grazing vs. TMR), concentrate supplementation based on individual milk production, trait definitions (RFIg vs. RFIp), and $\mathrm{CH}_{4}$ emission phenotype $\left(\mathrm{CH}_{4}\right.$ production vs. $\left.\mathrm{CH}_{4} \mathrm{c}\right)$, as well as $\mathrm{CH}_{4}$ measurement methods (sniffers, GreenFeed, and $\mathrm{SF}_{6}$ ). Within the present study, however, the differences in genetic correlations between GHG traits with RFIg and RFIp in DNK and NLD are likely a result of genetic heterogeneity due to lactation stage or energy density of different diets, particularly whether concentrate was supplemented based on individual milk production. In DNK, 434 primiparous cows had repeated weekly records for GHG traits, $47 \%$ of which had full-lactation concurrent records for GHG traits and FI traits. In NLD, 654 primiparous cows had repeated weekly records for GHG traits for part of lactation, $42 \%$ of which had DMI records in the first 70 DIM; as a result, no cows had concurrent GHG and FI traits in NLD. In NLD, feed efficiency is largely estimated for the first 70 DIM and correlated with GHG traits from 70 to 305 DIM. Both GHG traits and feed efficiency change over the course of lactation, particularly between early and mid to late lactation, thus their genetic correlations with each other at different lactation stages are likely to differ as well (Li et al., 2017; Pszczola et al., 2017).

Within NLD, the genetic correlations between feed efficiency traits, which assumed constant partial regression coefficients (i.e., RFIg and RFIp) and GHG, were opposite in sign to RFIss, which allowed for heterogeneity due to ration. However, standard errors of these genetic correlations in NLD were large. Heterogeneity in feed efficiency traits due to different experimental rations is well established (Tempelman et al., 2015) and there is evidence for heterogeneity in regression coefficients between $\mathrm{CH}_{4} \mathrm{C}$ and milk yield in herds using different feeding regimens, as well as different levels of concentrate supplementation in AMS based on individual milk yield (Bell et al., 2014). Importantly, in DNK, all GHG traits and FI traits are recorded on cows in AMS supplemented with concentrate based on milk production. In contrast, in NLD during the DMI recording period, cows are fed TMR (1-70 DIM) without additional concentrate supplementation and then fed a partial mixed ration and concentrate supplemented in the AMS based on individual milk production (71-305 DIM) when GHG traits are recorded. 
Increasing the concentrate-to-forage ratio reduces $\mathrm{CH}_{4}$ production relative to DMI (Bell et al., 2014); a shortcoming of using DMI to calculate feed efficiency traits is that energy and feed composition are not accounted for and individual forage-to-concentrate ratios for cows are ignored. As a result, cows with higher milk production are fed a more energy dense diet, with a higher concentrate-to-forage ratio, which reduces $\mathrm{CH}_{4}$ production. By expressing feed efficiency as RFIss and accounting for heterogeneity due to different rations, differences in feed composition and energy density might be better accounted for in NLD, resulting in consensus positive genetic correlations between GHG traits and RFIss in DNK and NLD. Because most DMI records are recorded in small-scale research herds in which numerous dietary trials are conducted and there is large variation in dietary rations across commercial herds (Bell et al., 2014), and the sniffer method requires AMS herds which supplement additional concentrate based on milk production, further research is needed to evaluate possible genotype by environment interactions due to diets.

\section{Prediction Accuracy of Selection Indices for DMI and Feed Efficiency}

When assessing the potential of a large-scale indicator trait to a scarcely recorded and expensive breeding goal trait, it is important to account for the genetic correlations and the value of increased records of the indicator trait. The accuracy of selection indices for DMI and feed efficiency traits was assessed for bulls using different combinations of FI and GHG traits based on the estimated genetic and phenotypic (co) variances and numbers of daughters with single weekly averaged records. For DMI, including only GHG traits had limited gains compared with including FPCM and BW in both countries. However, using GHG traits as well as FPCM and BW for a bull with 100 daughters gave high accuracies in both countries, almost negating the need for DMI records on daughters (0.97 in DNK and 0.83 in NLD).

The accuracy of RFIg using only FPCM and BW was zero, as compared with the accuracy using GHG traits (0.51 in DNK and 0.46 in NLD). The accuracy of RFIp only using FPCM and BW was modest (0.48 in DNK and 0.25 in NLD) and similar to that for GHG traits (0.48 in DNK and 0.57 in NLD). Similarly, ManzanillaPech et al. (2016) found accuracies for DMI and RFIp using conformation traits (stature, chest width, and body depth) along with BW and milk energy output in the US and NLD Holstein populations. Bull accuracies for DMI using conformation traits were 0.43 in NLD and 0.63 in the United States and further increased to 0.79 in NLD and 0.97 in the United States with the addition of BW and milk energy output (ManzanillaPech et al., 2016). Although the accuracies were low for RFIp in NLD (0.17) but substantial in the United States (0.97), the 2 populations had very different genetic correlations between RFIp and predictor traits (Manzanilla-Pech et al., 2016).

Across all 3 feed efficiency traits and DMI, having 100 daughters with FPCM, BW, and GHG traits resulted in sufficiently high accuracies to almost negate the need for DMI records. This highlights the potential of high-throughput automated indicator traits in the AMS to improve bull EBV accuracies for scarcely recorded traits if genetic parameters are known. However, much larger studies are required to elucidate whether and how potential sources of heterogeneity in the relationships between FI and GHG traits (such as lactation stage or different diets) can influence the genetic relationships between feed efficiency and GHG.

\section{CONCLUSIONS}

This study demonstrated genetic variation for feed efficiency traits and the concentration of $\mathrm{CH}_{4}$ and $\mathrm{CO}_{2}$ in the breath of lactating Holstein cattle. However, feed efficiency traits were differentially genetically correlated with breath concentration GHG traits in both magnitude and sign, depending on the population and the trait definitions of feed efficiency, which may be due to the influence of lactation stage and diet-induced heterogeneity. Despite differences in the sign of genetic correlations between GHG traits and feed efficiency traits, the magnitude of correlations resulted in the relatively cheap GHG traits improving the accuracies of highly valuable feed efficiency traits. Across all 3 feed efficiency traits and DMI, having 100 daughters with FPCM, BW, and GHG traits resulted in sufficiently high accuracies to almost negate the need for DMI records. These findings open the possibility for using GHG traits as large-scale indicator traits for genetically improving the accuracies of feed efficiency in dairy cows.

\section{ACKNOWLEDGMENTS}

The authors acknowledge the generosity of the anonymous Danish and Dutch farmers and research herds who allowed GHG sampling of their cows. We are grateful for the kind assistance of Per Madsen and Mahmoud Shirali (Center for Quantitative Genetics and Genomics, Aarhus University, Denmark) with calculations for standard errors of correlations between 
RFIg and other traits; Ghyslaine Schopen, Sabine van Engelen, Wijbrand Ouweltjes (Wageningen University \& Research, Wageningen, the Netherlands), and Martin Bjerring (Department of Animal Science, Aarhus University, Denmark) for their curatorship of the Dutch and Danish datasets and technical expertise. G. F. Difford benefited from an Erasmus-Mundus fellowship and a grant by the Innovation Fund Denmark project REMRUM, within the framework of the European Graduate School in Animal Breeding and Genetics. The authors express gratitude to the EU COST-action METHAGENE network for the interesting discussions and input. The authors declare there is no conflict of interest. Jan Lassen is employed at Viking Genetics, and this organization has no financial or other interests in this research.

\section{REFERENCES}

Aubry, A., and T. Yan. 2015. Meta-analysis of calorimeter data to establish relationships between methane and carbon dioxide emissions or oxygen consumption for dairy cattle. Anim. Nutr. 1:128 134. https://doi.org/10.1016/j.aninu.2015.08.015.

Beerda, B., W. Ouweltjes, L. B. J. Šebek, J. J. Windig, and R. F. Veerkamp. 2007. Effects of genotype by environment interactions on milk yield, energy balance, and protein balance. J. Dairy Sci. 90:219-228. https://doi.org/10.3168/jds.S0022-0302(07)72623-1.

Bell, M. J., S. L. Potterton, J. Craigon, N. Saunders, R. H. Wilcox, M. Hunter, J. R. Goodman, and P. C. Garnsworthy. 2014. Variation in enteric methane emissions among cows on commercial dairy farms. Animal 8:1540-1546. https://doi.org/10.1017/ S1751731114001530.

Berry, D. P., M. P. Coffey, J. E. Pryce, Y. de Haas, P. Løvendahl, N. Krattenmacher, J. J. Crowley, Z. Wang, D. Spurlock, K. Weigel, K. Macdonald, and R. F. Veerkamp. 2014. International genetic evaluations for feed intake in dairy cattle through the collation of data from multiple sources. J. Dairy Sci. 97:3894-3905. https://doi .org/10.3168/jds.2013-7548.

Berry, D. P., and J. J. Crowley. 2013. Cell Biology Symposium: Genetics of feed efficiency in dairy and beef cattle. J. Anim. Sci. 91:1594-1613. https://doi.org/10.2527/jas.2012-5862.

Breider, I. S., E. Wall, P. C. Garnsworhty, and J. E. Pryce. 2018. Genetic relationships between methane emission and milk yield, live weight and dry matter intake. Page 134 in Proc. World Congr. Genet. Appl. Livest. Prod., 11, Auckland, New Zealand. http:// www.wcgalp.org/proceedings/2018/genetic-relationships-between -methane-emission-and-milk-yield-live-weight-and-dry.

CVB. 2008. Tabellenboek Veevoeding (Dutch Feed Table Booklet). Centraal Veevoeder Bureau, Lelystad, the Netherlands.

de Haas, Y., M. P. L. Calus, R. F. Veerkamp, E. Wall, M. P. Coffey, H. D. Daetwyler, B. J. Hayes, and J. E. Pryce. 2012. Improved accuracy of genomic prediction for dry matter intake of dairy cattle from combined European and Australian data sets. J. Dairy Sci. 95:6103-6112. https://doi.org/10.3168/jds.2011-5280.

de Haas, Y., J. J. Windig, M. P. L. Calus, J. Dijkstra, M. de Haan, A. Bannink, and R. F. Veerkamp. 2011. Genetic parameters for predicted methane production and potential for reducing enteric emissions through genomic selection. J. Dairy Sci. 94:6122-6134. https://doi.org/10.3168/jds.2011-4439.

Difford, G. F., J. Lassen, and P. Løvendahl. 2016. Interchangeability between methane measurements in dairy cows assessed by comparing precision and agreement of two non-invasive infrared methods. Comput. Electron. Agric. 124:220-226. https://doi.org/10.1016/j .compag.2016.04.010.
Difford, G. F., D. W. Olijhoek, A. L. F. Hellwing, P. Lund, M. A. Bjerring, Y. de Haas, J. Lassen, and P. Løvendahl. 2018. Ranking cows' methane emissions under commercial conditions with sniffers versus respiration chambers. Acta Agric. Scand. A Anim. Sci. 68:25-32. https://doi.org/10.1080/09064702.2019.1572784.

Donoghue, K. A., T. Bird-Gardiner, P. F. Arthur, R. M. Herd, and R. F. Hegarty. 2016. Genetic and phenotypic variance and covariance components for methane emission and postweaning traits in Angus cattle. J. Anim. Sci. 94:1438-1445. https://doi.org/10.2527/ jas.2015-0065.

Falconer, D., and T. Mackay. 1996. Introduction to Quantitative Genetics. 4th ed. Longman Scientific and Technical, Essex, UK.

FAO. 2010. Greenhouse Gas Emissions from the Dairy Sector. A Life Cycle Assessment. Accessed Dec. 5, 2017. http://www.fao.org/ docrep/012/k7930e/k7930e00.pdf.

Garnsworthy, P. C., J. Craigon, J. H. Hernandez-Medrano, and N. Saunders. 2012a. Variation among individual dairy cows in methane measurements made on farm during milking. J. Dairy Sci 95:3181-3189. https://doi.org/10.3168/jds.2011-4606.

Garnsworthy, P. C., J. Craigon, J. H. Hernandez-Medrano, and N. Saunders. 2012b. On-farm methane measurements during milking correlate with total methane production by individual dairy cows. J. Dairy Sci. 95:3166-3180. https://doi.org/10.3168/jds.2011 -4605 .

Hailemariam, D., G. Manafiazar, J. Basarab, F. Miglior, G. Plastow, and Z. Wang. 2016. Greenhouse gas emission related traits differ in RFI divergent lactating dairy cows. J. Anim. Sci. 94(Suppl_5):191. (Abstr.) https://doi.org/10.2527/jam2016-0394.

Hemme, T., M. M. Uddin, and O. A. Ndambi. 2014. Benchmarking cost of milk production in 46 countries. J. Rev. Glob. Econ. 3:254270.

Hristov, A. N., J. Oh, J. L. Firkins, J. Dijkstra, E. Kebreab, G. Waghorn, H. P. S. Makkar, A. T. Adesogan, W. Yang, C. Lee, P. J. Gerber, B. Henderson, and J. M. Tricarico. 2013. Special TopicsMitigation of methane and nitrous oxide emissions from animal operations: I. A review of enteric methane mitigation options. J. Anim. Sci. 91:5045-5069. https://doi.org/10.2527/jas2013-6583.

Huhtanen, P., E. H. Cabezas-Garcia, S. Utsumi, and S. Zimmerman. 2015. Comparison of methods to determine methane emissions from dairy cows in farm conditions. J. Dairy Sci. 98:3394-3409. https://doi.org/10.3168/jds.2014-9118.

Jensen, J., I. Mao, B. Andersen, and P. Madsen. 1992. Phenotypic and genetic relationships between residual energy intake and growth, feed intake, and carcass traits of young bulls. J. Anim. Sci. 70:386395. https://doi.org/10.2527/1992.702386x.

Johnson, K. A., and D. E. Johnson. 1995. Methane emissions from cattle. J. Anim. Sci. 73:2483-2492. https://doi.org/10.2527/1995 $.7382483 \mathrm{x}$.

Jonker, A., S. M. Hickey, S. J. Rowe, P. H. Janssen, G. H. Shackell, S. Elmes, W. E. Bain, J. Wing, G. J. Greer, B. Bryson, S. MacLean, K. G. Dodds, C. S. Pinares-Patiño, E. A. Young, K. Knowler, N. K. Pickering, and J. C. McEwan. 2018. Genetic parameters of methane emissions determined using portable accumulation chambers in lambs and ewes grazing pasture and genetic correlations with emissions determined in respiration chambers. J. Anim. Sci. 96:3031-3042. https://doi.org/10.1093/jas/sky187.

Kennedy, B. W., J. H. van Der Werf, and T. H. Meuwissen. 1993. Genetic and statistical properties of residual feed intake. J. Anim. Sci. 71:3239-3250.

Koenen, E. P. C., and R. F. Veerkamp. 1998. Genetic covariance functions for live weight, condition score, and dry-matter intake measured at different lactation stages of Holstein Friesian heifers. Livest. Prod. Sci. 57:67-77. https://doi.org/10.1016/S0301 -6226(98)00159-6.

Lassen, J., and P. Løvendahl. 2016. Heritability estimates for enteric methane emissions from Holstein cattle measured using noninvasive methods. J. Dairy Sci. 99:1959-1967. https://doi.org/10 $.3168 /$ jds. $2015-10012$.

Lassen, J., P. Løvendahl, and J. Madsen. 2012. Accuracy of noninvasive breath methane measurements using Fourier transform infra- 
red methods on individual cows. J. Dairy Sci. 95:890-898. https:/ /doi.org/10.3168/jds.2011-4544.

Li, B., B. Berglund, W. F. Fikse, J. Lassen, M. H. Lidauer, P. Mäntysaari, and P. Løvendahl. 2017. Neglect of lactation stage leads to naive assessment of residual feed intake in dairy cattle. J. Dairy Sci. 100:9076-9084. https://doi.org/10.3168/jds.2017-12775.

Li, B., W. F. Fikse, J. Lassen, M. H. Lidauer, P. Løvendahl, P. Mäntysaari, and B. Berglund. 2016. Genetic parameters for dry matter intake in primiparous Holstein, Nordic Red, and Jersey cows in the first half of lactation. J. Dairy Sci. 99:7232-7239. https://doi.org/ 10.3168/jds.2015-10669.

Li, B., W. F. Fikse, P. Løvendahl, J. Lassen, M. H. Lidauer, P. Mäntysaari, and B. Berglund. 2018. Genetic heterogeneity of feed intake, energy-corrected milk, and body weight across lactation in primiparous Holstein, Nordic Red, and Jersey cows. J. Dairy Sci. 101:10011-10021. https://doi.org/10.3168/jds.2018-14611.

Løvendahl, P., G. F. Difford, M. G. G. Chagunda, P. Huhtanen, M. H. Lidauer, J. Lassen, and P. Lund. 2018. Review: Selecting for improved feed efficiency and reduced methane emissions in dairy cattle. Animal 12(s2):s336-s349. https://doi.org/10.1017/ S1751731118002276.

Lu, Y., M. J. Vandehaar, D. M. Spurlock, K. A. Weigel, L. E. Armentano, C. R. Staples, E. E. Connor, Z. Wang, N. M. Bello, and R. J. Tempelman. 2015. An alternative approach to modeling genetic merit of feed efficiency in dairy cattle. J. Dairy Sci. 98:6535-6551. https://doi.org/10.3168/jds.2015-9414.

Lu, Y., M. J. Vandehaar, D. M. Spurlock, K. A. Weigel, L. E. Armentano, C. R. Staples, E. E. Connor, Z. Wang, M. Coffey, R. F. Veerkamp, Y. de Haas, and R. J. Tempelman. 2017. Modeling genetic and nongenetic variation of feed efficiency and its partial relationships between component traits as a function of management and environmental factors. J. Dairy Sci. 100:412-2427. https: //doi.org/10.3168/jds.2016-11491.

Madsen, J., B. S. Bjerg, T. Hvelplund, M. R. Weisbjerg, and P. Lund. 2010. Methane and carbon dioxide ratio in excreted air for quantification of the methane production from ruminants. Livest. Sci. 129:223-227. https://doi.org/10.1016/j.livsci.2010.01.001.

Madsen, P. 2012. DMU trace, A program to trace the pedigree for a sub set of animals from a larger pedigree file. http://dmu.agrsci $. \mathrm{dk} / \mathrm{DMU}$.

Madsen, P., and J. Jensen. 2014. A user's guide to DMU, version 6 , release 5.0. Center for Quantitative Genetics and Genomics, Department of Molecular Biology and Genetics, Aarhus University Research Centre Foulum, Tjele, Denmark.

Manafiazar, G., L. Goonewardene, F. Miglior, D. H. Crews Jr., J. A. Basarab, E. Okine, and Z. Wang. 2016. Genetic and phenotypic correlations among feed efficiency, production and selected conformation traits in dairy cows. Animal 11:381-389. https://doi.org/ 10.1017/S1751731115002281.

Manzanilla-Pech, C. I. V., R. F. Veerkamp, R. J. Tempelman, M. L. van Pelt, K. A. Weigel, M. VandeHaar, T. J. Lawlor, D. M. Spurlock, L. E. Armentano, C. R. Staples, M. Hanigan, and Y. De Haas. 2016. Genetic parameters between feed-intake-related traits and conformation in 2 separate dairy populations-the Netherlands and United States. J. Dairy Sci. 99:443-457. https://doi.org/10 .3168/jds.2015-9727.

Manzanilla Pech, C. I. V. I. V., R. F. F. Veerkamp, M. P. L. P. L. Calus, R. Zom, A. van Knegsel, J. E. E. Pryce, and Y. De Haas. 2014. Genetic parameters across lactation for feed intake, fat- and protein-corrected milk, and liveweight in first-parity Holstein cattle. J. Dairy Sci. 97:5851-5862. https://doi.org/10.3168/jds.2014 -8165 .

Negussie, E., J. Lehtinen, P. Mäntysaari, A. R. Bayat, A.-E. Liinamo, E. A. Mäntysaari, and M. H. Lidauer. 2017. Non-invasive individual methane measurement in dairy cows. Animal 4:890-899. https://doi.org/10.1017/S1751731116002718.

Negussie, E., P. Mantysaari, E. A. Mantysaari, and M. Lidauer. 2014. Animal wise variation in enteric output traits and its relationship with feed efficiency in dairy cattle: A longitudinal model analysis. Pages 2-4 in Proc. 10th World Congr. Genet. Appl. Livest. Prod, Vancouver, Canada. http://www.wcgalp.org/proceedings/ 2014/animal-wise-variation-enteric-methane-output-traits-and-its -relationship-feed.

Nielsen, H. M., N. C. Friggens, P. Løvendahl, J. Jensen, and K. L. Ingvartsen. 2003. Influence of breed, parity, and stage of lactation on lactational performance and relationship between body fatness and live weight. Livest. Prod. Sci. 79:119-133. https://doi.org/10 .1016/S0301-6226(02)00146-X.

Olijhoek, D. W., P. Løvendahl, J. Lassen, A. L. F. Hellwing, J. Höglund, M. R. Weisbjerg, S. J. Noel, F. McLean, O. Højberg, and P. Lund. 2018. Methane production, rumen fermentation, and diet digestibility of Holstein and Jersey dairy cows being divergent in residual feed intake and fed at two forage-to concentrate ratios. J. Dairy Sci. 101:9926-9940. https://doi.org/10.3168/jds.2017-14278.

Pinares-Patiño, C. S., and H. Clark. 2008. Reliability of the sulfur hexafluoride tracer technique for methane emission measurement from individual animals: An overview. Aust. J. Exp. Agric. 48:223229. https://doi.org/10.1071/EA07297.

Pinares-Patiño, C. S., S. M. Hickey, E. A. Young, K. G. Dodds, S. MacLean, G. Molano, E. Sandoval, H. Kjestrup, R. Harland, C. Hunt, N. K. Pickering, and J. C. McEwan. 2013. Heritability estimates of methane emissions from sheep. Animal 7(s2):316-321. https:// doi.org/10.1017/S1751731113000864.

Pszczola, M., K. Rzewuska, S. Mucha, and T. Strabel. 2017. Heritability of methane emissions from dairy cows over a lactation measured on commercial farms. J. Anim. Sci. 95:4813-4819. https: //doi.org/10.2527/jas2017.1842.

Ramin, M., and P. Huhtanen. 2013. Development of equations for predicting methane emissions from ruminants. J. Dairy Sci. 96:24762493. https://doi.org/10.3168/jds.2012-6095.

Shirali, M., A. B. Strathe, T. Mark, B. Nielsen, and J. Jensen. 2017. Joint analysis of longitudinal feed intake and single recorded production traits in pigs using a novel Horizontal model. J. Anim. Sci. 95:1052-1062. https://doi.org/10.2527/jas.2016.0606.

Shirali, M., P. F. Varley, and J. Jensen. 2018. Bayesian estimation of direct and correlated responses to selection on linear or ratio expressions of feed efficiency in pigs. Genet. Sel. Evol. 50:33. https: /doi.org/10.1186/s12711-018-0403-0.

Sjaunja, L. O., L. Baevre, L. Junkkarinen, J. Pedersen, and J. Setala. 1991. A Nordic Proposal for an Energy Corrected Milk (ECM) Formula. EAAP Publication 50, Performance Recording of Animals: State of the Art 1990. Centre for Agricultural Publishing and Documentation (PUDOC), Wageningen, the Netherlands.

Sloniewski, K., I. L. Mao, J. Jensen, and P. Madsen. 2005. Changes in body weight and frame and its genetic variation during the productive life of dairy cows. Acta Agric. Scand. A Anim. Sci 55:128-136. https://doi.org/10.1080/09064700500478564.

Søndergaard, E., M. K. Sorensen, I. L. Mao, and J. Jensen. 2002. Genetic parameters of production, feed intake, body weight, body composition, and udder health in lactating dairy cows. Livest. Prod. Sci. 77:23-34. https://doi.org/10.1016/S0301-6226(02)00023 -4 .

Tempelman, R. J., D. M. Spurlock, M. Coffey, R. F. Veerkamp, L. E. Armentano, K. A. Weigel, Y. de Haas, C. R. Staples, E. E. Connor, Y. Lu, and M. J. VandeHaar. 2015. Heterogeneity in genetic and nongenetic variation and energy sink relationships for residual feed intake across research stations and countries. J. Dairy Sci 98:2013-2026. https://doi.org/10.3168/jds.2014.8510.

Vallimont, J. E., C. D. Dechow, J. M. Daubert, M. W. Dekleva, J. W. Blum, C. M. Barlieb, W. Liu, G. A. Varga, A. J. Heinrichs, and C. R. Baumrucker. 2010. Genetic parameters of feed intake, production, body weight, body condition score, and selected type traits of Holstein cows in commercial tie-stall barns. J. Dairy Sci. 93:4892-4901. https://doi.org/10.3168/jds.2010-3189.

Van Der Werf, J. H. J. 2017. Teaching Software Used for Quantitative Genetics at UNE. Accessed Jun. 5, 2017. https://jvanderw.une .edu.au/software.htm.

van Engelen, S., H. Bovenhuis, P. P. J. van der Tol, and M. H. P. W. Visker. 2018. Genetic background of methane emission by Dutch Holstein Friesian cows measured with infrared sensors in automatic milking systems. J. Dairy Sci. 101:2226-2234. https://doi .org/10.3168/jds.2017-13441. 
van Knegsel, A. T. M., G. J. Remmelink, S. Jorjong, V. Fievez, and B. Kemp. 2014. Effect of dry period length and dietary energy source on energy balance, milk yield, and milk composition of dairy cows. J. Dairy Sci. 97:1499-1512. https://doi.org/10.3168/jds.2013-7391.

Veerkamp, R. F. 1998. Selection for economic efficiency of dairy cattle using information on live weight and feed intake: A review. J. Dairy Sci. 81:1109-1119. https://doi.org/10.3168/jds.S0022 -0302(98)75673-5.

Veerkamp, R. F., G. C. Emmans, R. Cromie, and G. Simm. 1995. Variance components for residual feed intake in dairy cows. Livest. Prod. Sci. 41:111-120. https://doi.org/10.1016/0301 -6226(94)00056-D.

Veerkamp, R. F., J. K. Oldenbroek, H. J. Van der Gaast, and J. H. J. Van Der Werf. 2000. Genetic correlation between days until start of luteal activity and milk yield, energy balance, and live weights. J. Dairy Sci. 83:577-583. https://doi.org/10.3168/jds .S0022-0302(00)74917-4.

Wallén, S. E., M. Lillehammer, and T. H. E. Meuwissen. 2017. Strategies for implementing genomic selection for feed efficiency in dairy cattle breeding schemes. J. Dairy Sci. 100:6327-6336. https://doi .org/10.3168/jds.2016-11458.

Wu, L., P. W. G. G. Koerkamp, and N. Ogink. 2018. Uncertainty assessment of the breath methane concentration method to determine methane production of dairy cows. J. Dairy Sci. 101:15541564. https://doi.org/10.3168/jds.2017-12710.
Yao, C., G. de los Campos, M. J. VandeHaar, D. M. Spurlock, L. E. Armentano, M. Coffey, Y. de Haas, R. F. Veerkamp, C. R. Staples, E. E. Connor, Z. Wang, M. D. Hanigan, R. J. Tempelman, and K. A. Weigel. 2017. Use of genotype $\times$ environment interaction model to accommodate genetic heterogeneity for residual feed intake, dry matter intake, net energy in milk, and metabolic body weight in dairy cattle. J. Dairy Sci. 100:2007-2016. https://doi.org/10.3168/ jds.2016-11606.

Zom, R. L. G., G. André, and A. M. van Vuuren. 2012. Development of a model for the prediction of feed intake by dairy cows: 1 . Prediction of feed intake. Livest. Sci. 143:43-57. https://doi.org/10 .1016/j.livsci.2011.08.014.

\section{ORCIDS}

G. F. Difford (ㄱ) https://orcid.org/0000-0002-6792-8722

P. Løvendahl (1) https://orcid.org/0000-0002-9852-2944

R. F. Veerkamp ๑ https://orcid.org/0000-0002-5240-6534

H. Bovenhuis ๑ https://orcid.org/0000-0002-9074-5334

M. H. P. W. Visker () https://orcid.org/0000-0002-9276-3034

Y. de Haas ํ https://orcid.org/0000-0002-4331-4101 